\title{
Simulations of a cold-air pool associated with elevated wintertime ozone in the Uintah Basin, Utah
}

\author{
E. M. Neemann ${ }^{1}$, E. T. Crosman ${ }^{1}$, J. D. Horel ${ }^{1}$, and L. Avey $^{2}$ \\ ${ }^{1}$ Department of Atmospheric Sciences, University of Utah, Salt Lake City, Utah, USA \\ ${ }^{2}$ Utah Division of Air Quality, Salt Lake City, Utah, USA \\ Correspondence to: J. Horel (john.horel@utah.edu)
}

Received: 12 May 2014 - Published in Atmos. Chem. Phys. Discuss.: 17 June 2014

Revised: 24 November 2014 - Accepted: 25 November 2014 - Published: 9 January 2015

\begin{abstract}
Numerical simulations are used to investigate the meteorological characteristics of the 31 January-6 February 2013 cold-air pool in the Uintah Basin, Utah, and the resulting high ozone concentrations. Flow features affecting cold-air pools and air quality in the Uintah Basin are studied, including the following: penetration of clean air into the basin from across the surrounding mountains, elevated easterlies within the inversion layer, and thermally driven slope and valley flows. The sensitivity of the boundary layer structure to snow cover variations and cloud microphysics are also examined. Snow cover increases boundary layer stability by enhancing the surface albedo, reducing the absorbed solar insolation at the surface, and lowering near-surface air temperatures. Snow cover also increases ozone levels by enhancing solar radiation available for photochemical reactions. Icedominant clouds enhance cold-air pool strength compared to liquid-dominant clouds by increasing nocturnal cooling and decreasing longwave cloud forcing.
\end{abstract}

\section{Introduction}

High concentrations of near-surface ozone have an adverse impact on human health, including respiratory irritation and inflammation, reduced lung function, aggravated asthma, and long-term lung damage (Lippmann, 1993; Bell et al., 2004). Ozone is formed through photochemical reactions of precursor pollutants, typically nitrogen oxides $\left(\mathrm{NO}_{\mathrm{x}}\right)$ and volatile organic compounds (VOCs), emitted from industrial sources and vehicles (Pollack et al., 2013). Once thought to primarily be an urban, summertime problem (due to the high insolation required for photochemical reactions), high ozone levels and associated precursor pollutants have recently been detected during the wintertime in snow-covered rural basins with significant industrial fossil fuel extraction activities (Schnell et al., 2009; Helmig et al., 2014; Lee et al., 2014; Warneke et al., 2014a, b; Li et al., 2014). Snow cover increases the surface albedo and near-surface actinic flux (quantity of light available to molecules) leading to photolysis rates notably larger $(\sim 50 \%)$ than those observed in summer (Schnell et al., 2009). In addition, the shallow and highly stable boundary layer often observed during the wintertime in snowcovered rural basins further exacerbates the problem by trapping the high ozone concentrations in the lowest several hundred meters of the atmosphere (Fig. 1).

High levels of ozone were first detected in northeast Utah's Uintah Basin in 2009, when $8 \mathrm{~h}$ average concentrations were over $100 \mathrm{ppb}$ (Lyman et al., 2014). This value was well above the US Environmental Protection Agency's (EPA) National Ambient Air Quality Standard (NAAQS) of 75 ppb (EPA, 2014), and far above the background levels of ozone near the earth's surface that typically range between 20 and $45 \mathrm{ppb}$ (EPA, 2006). Fossil fuel production has increased in the Uintah Basin over the last several years and will likely continue to increase. Currently, there are over 11200 producing wells in the basin (Helmig et al., 2014) and over 3800 additional permit applications since the beginning of 2012. During the past several winters, extensive scientific research has been conducted in the Uintah Basin to better understand the wintertime rural ozone problem (Edwards et al., 2013; Lyman and Shorthill, 2013; Stoeckenius and McNally, 2014; Helmig et al., 2014; Warneke et al., 2014a, b). Considerable variations in late winter snow cover, which modulates the occurrence of high ozone events in the Uintah Basin, are evident 


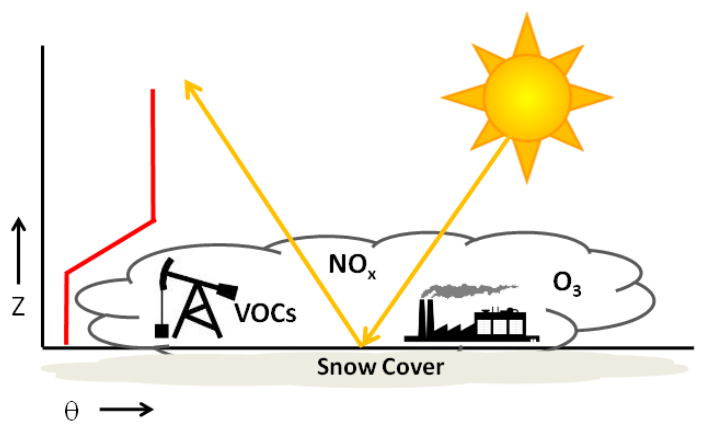

Figure 1. Schematic of factors contributing to high ozone concentrations. Potential temperature profile (red line) with stable layer trapping ozone precursors $\left(\mathrm{NO}_{\mathrm{x}}\right.$ and VOCs) within the cold-air pool. Snow cover reflects solar radiation, increases photolysis rates, and leads to enhanced ozone $\left(\mathrm{O}_{3}\right)$ concentrations near the surface. Ice fogs are common in the cold-air pool.

from year to year. Snow cover was largely absent from the basin during February 2009, 2012, and 2014 and ozone levels remained low during those months, while February 2010, 2011, and 2013 saw extensive snow cover and several high ozone episodes.

The Uinta Mountains to the north, Wasatch Range to the west, and Tavaputs Plateau to the south often confine cold air during winter within the topographic depression of the Uintah Basin (Fig. 2). Such cold-air pools (CAPs) form when synoptic and mesoscale processes lead to persistent stable stratification in the boundary layer resulting from a combination of warming aloft and cooling near the surface (Lareau et al., 2013). The high terrain encompassing the basin and its large horizontal extent leave its central core less affected by weak synoptic-scale weather systems, which results in longer-lived CAPs than those observed in other locales (Zängl, 2005b; Lareau et al., 2013; Lareau and Horel, 2014; Sheridan et al., 2014). CAPs are often associated with low clouds, fog, freezing precipitation, hazardous ground and air travel, and elevated levels of particulate air pollution in valleys and basins (Whiteman et al., 2001; Malek et al., 2006; Silcox et al., 2012; Lareau et al., 2013; Lareau, 2014; Lareau and Horel, 2014).

Numerical studies have examined the lifecycle of CAPs for a variety of idealized (Zängl, 2005a; Katurji and Zhong, 2012; Lareau, 2014) and actual topographic basins (Whiteman et al., 2001; Clements et al., 2003; Zängl, 2005b; Billings et al., 2006; Reeves and Stensrud, 2009; Reeves et al., 2011; Lareau et al., 2013; Lareau and Horel, 2014; $\mathrm{Lu}$ and Zhong, 2014). However, relatively few studies have examined the impact of snow cover, clouds, and cloud microphysics on CAP formation and evolution. Zängl (2005a) found that the limited heat conductivity of fresh snow was important for efficient cooling of the air near the surface. Comparing simulations with a snow-covered and grasscovered sinkhole floor suggested that the larger surface heat
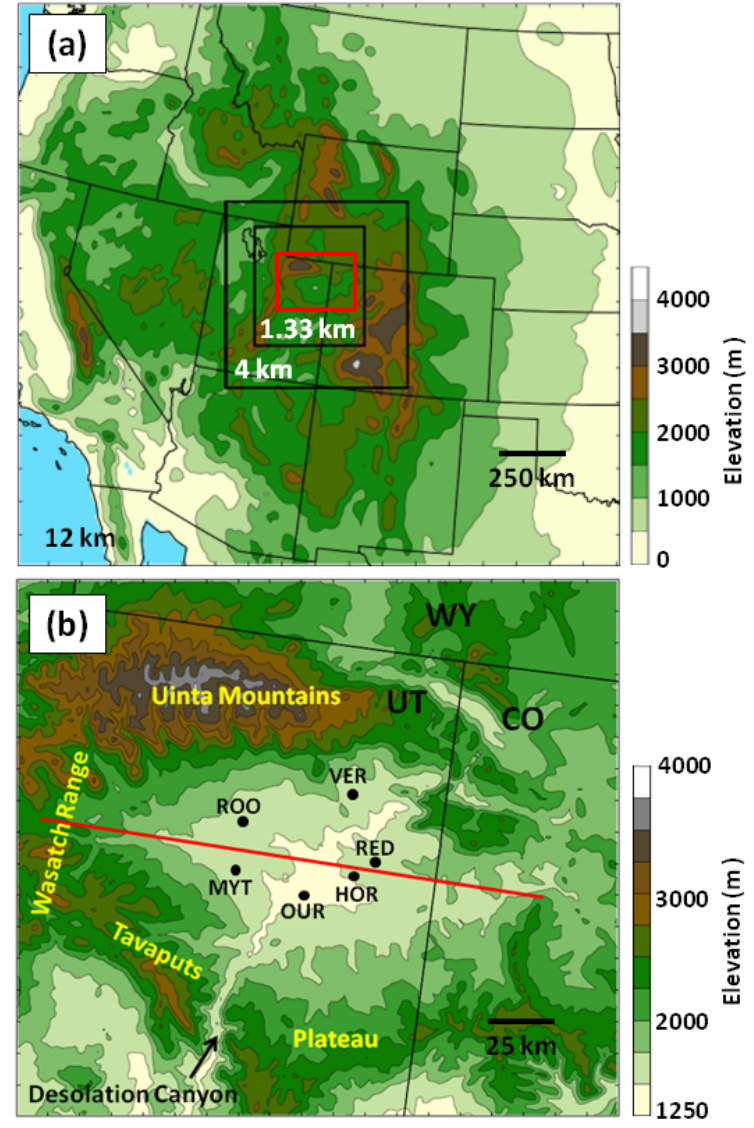

Figure 2. (a) WRF 12, 4, and $1.33 \mathrm{~km}$ domains with terrain contoured every $500 \mathrm{~m}$. (b) Uintah Basin sub-domain with terrain contoured every $250 \mathrm{~m}$ and major geographic features labeled. Black dots indicate locations of surface stations used for verification: Horsepool (HOR), Myton (MYT), Ouray (OUR), Red Wash (RED), Roosevelt (ROO), and Vernal (VER). Red box in (a) indicates closeup region shown in (b) and the red line in (b) indicates position of vertical cross sections shown later.

capacity of the grass floor resulted in more gradual cooling, smaller afternoon-morning temperature difference, weaker static stability, and no cloud cover. Billings et al. (2006) studied the impact of snow cover on a CAP in the Yampa Valley, Colorado and found that snow-free simulations were incapable of producing the CAP. Zängl (2005a) indirectly examined the effect of cloud particle phase on the formation of CAPs in the Gstettneralm sinkhole, Austria. He found that an efficient drying mechanism to remove fog was required, such as the nucleation and sedimentation of cloud ice; otherwise the enhanced cloud longwave radiation inhibits the low-level cooling necessary for a strong CAP. Numerical models often struggle to accurately simulate ice fogs that occur in some CAPs, largely because the underlying ice fog microphysics are not well understood (Gultepe et al., 2014).

While the influence of snow and cloud cover, inter-basin flows, and terrain-flow interactions on the evolution of the 
shallow, stable boundary layers associated with wintertime high ozone episodes in the Uintah Basin has been recognized, those impacts have only been partially explored (Lyman and Shorthill, 2013; Stoeckenius and McNally, 2014). In this study, a high ozone episode from 31 January to 6 February 2013 during the Uintah Basin Winter Ozone Study (UBWOS) is examined. The Weather Research and Forecasting (WRF) model is used to examine the sensitivity of CAP thermodynamic structure and wind flow regimes to variations in snow cover, specification of snow albedo, and cloud microphysics, while the Community Multi-Scale Air Quality (CMAQ) model is used to investigate the impact of snow cover on ozone concentrations. Section 2 briefly describes the numerical simulations and selected validating observations followed in Sect. 3 by an overview of the 31 January6 February case study and modeling results. Section 4 illustrates the sensitivity of simulated ozone concentrations during this period to snow cover. Discussion of the results follows in Sect. 5. For further information, see also Neemann (2014).

\section{Data and methods}

\subsection{WRF and CMAQ models and observations}

Table 1 summarizes the WRF version 3.5 model setup used in this study. The WRF model is non-hydrostatic, with a pressure-based, terrain-following vertical coordinate system. Simulations herein used 41 vertical levels with the lowest 20 levels within approximately $1 \mathrm{~km}$ of the terrain surface. Three telescoping, one-way nested domains were employed to place the highest-resolution nest over the Uintah Basin, with grid spacing of 12,4 , and $1.33 \mathrm{~km}$, respectively (Fig. 2a). Operational North American Mesoscale Model (NAM) analyses were used to initialize atmospheric and land surface variables (except for snow variables, see the following subsection) as well as provide the lateral boundary conditions for the outer domain at $6 \mathrm{~h}$ intervals. We evaluate the core period (17:00 MST 31 January 2013 to 17:00 MST 6 February 2013) of the CAP in the Uintah Basin that lasted from 30 January to 10 February 2013.

WRF output from the $4 \mathrm{~km}$ domain was imported into the Utah Division of Air Quality's (UDAQ) CMAQ model (version 5.0). The CMAQ model couples the meteorological data from WRF with an emission inventory from the Uintah Basin developed by UDAQ and chemistry-transport and photochemical subsystems to simulate concentrations for a variety of chemical compounds and pollutants (Byun and Schere, 2006). The emission inventory is for 2011 based on the growth of oil and gas activities since 2006 (Barickman, 2014). VOC oil and gas emission speciation profiles are provided by EPA's SPECIATE 4.3 database (EPA, 2011). Default (i.e., not Uintah Basin specific) speciation profiles are used, which assign generic natural gas flaring and crude oil storage tank profiles to the oil and gas emissions. Since the UDAQ inventory and CMAQ model are available at a resolution of $4 \mathrm{~km}$, that model was forced with WRF data from the $4 \mathrm{~km}$ nest (Fig. 2a).

Selected meteorological and surface ozone observations obtained during the UBWOS were used to describe the overall evolution of the CAP episode and to compare to the model results. A subset of six representative meteorological stations in the basin and archived in MesoWest (Horel et al., 2002) was selected to validate simulated $2 \mathrm{~m}$ temperature (see Fig. 2). Vertical profiles of temperature, dew point temperature, and wind from rawinsondes released at midday (11:00 MST) near Roosevelt on 1-6 February 2013 were used to evaluate the model's ability to reproduce the vertical structure of the boundary layer. Additional profiles of wind, temperature, and chemical species in the boundary layer available in the east-central portion of the basin as part of UBWOS are being examined by other researchers (e.g., Oltmans et al., 2014).

A Vaisala CL-31 laser ceilometer located at Roosevelt provided aerosol backscatter, the presence of low clouds, and an estimate of the depth of the aerosol layer. Finally, snowcloud and nighttime microphysics RGB imagery from the NASA Short-term Prediction Research and Transition Center (SPoRT) was used to determine the spatial extent of fog within the basin.

\subsection{Prescribing initial WRF snow cover in Uintah Basin}

While NAM analyses represented the spatial coverage of snow during the 31 January-6 February 2013 period fairly well, they overestimated snow depth and snow water equivalent (SWE) within the basin and underestimated them at higher elevations. In order to better represent the actual snow surface conditions, an "idealized" layer of snow and SWE was specified in the WRF initialization fields based on elevation in a manner similar to Alcott and Steenburgh (2013). This prescribed snow cover was determined using snowpack telemetry observations; National Operational Hydrologic Remote Sensing Center analyses; Moderate Resolution Imaging Spectroradiometer imagery; and manual and automated observations from the Community Collaborative Rain, Hail, and Snow Network, and those collected during the UBWOS campaign. As shown in Fig. 3c, the prescribed snow cover was applied within all model domains with no snow cover outside of the Uintah Basin below an elevation of $2000 \mathrm{~m}$ and a $17 \mathrm{~cm}$ snow depth from the basin floor up to an elevation of $2000 \mathrm{~m}$ (unless referenced specifically as a.g.l., all elevations are given in a.s.l.). Above $2000 \mathrm{~m}$, the snow depth was elevation dependent, increasing to $100 \mathrm{~cm}$ for elevations at $2900 \mathrm{~m}$ or higher.

In addition to poor representation of snow depth and SWE, the NAM analyses underestimated snow albedo relative to observed shortwave radiation measurements at Horsepool 
Table 1. Summary of WRF setup and parameterizations.

\begin{tabular}{lll}
\hline Parameter & Chosen setup & Reference \\
\hline Initial/boundary conditions & NAM analysis & \\
Vertical levels & 41 & \\
Domains & 3 one-way nests & \\
Resolution & $12,4,1.33 \mathrm{~km}$ & \\
Time Step & $45,15,5 \mathrm{~s}$ & Thompson et al. (2008) \\
Microphysics & Thompson & Iacono et al. (2008) \\
Shortwave radiation & RRTMG & Iacono et al. (2008) \\
Longwave radiation & RRTMG & Janjic (1994) \\
Boundary layer & Mellor-Yamada-Janjic (MYJ) & \\
Surface layer & Eta similarity & Chen and Dudhia (2001) \\
Land surface & Noah & Kain (2004) \\
Cumulus & Kain-Fritsch (12 km domain only) & \\
Diffusion & Second order on coordinate surfaces & \\
\hline
\end{tabular}

Table 2. Overview of WRF simulations.

\begin{tabular}{llll}
\hline $\begin{array}{l}\text { Simulation } \\
\text { name }\end{array}$ & Prescribed snow cover & $\begin{array}{l}\text { Cloud ice } \\
\text { sedimentation }\end{array}$ & $\begin{array}{l}\text { Cloud ice auto- } \\
\text { conversion to snow }\end{array}$ \\
\hline BASE & Full Snow in basin & ON & ON \\
FULL & Full Snow in basin & OFF & OFF \\
NONE & No Snow below $2000 \mathrm{~m}$ in basin & OFF & OFF \\
\hline
\end{tabular}
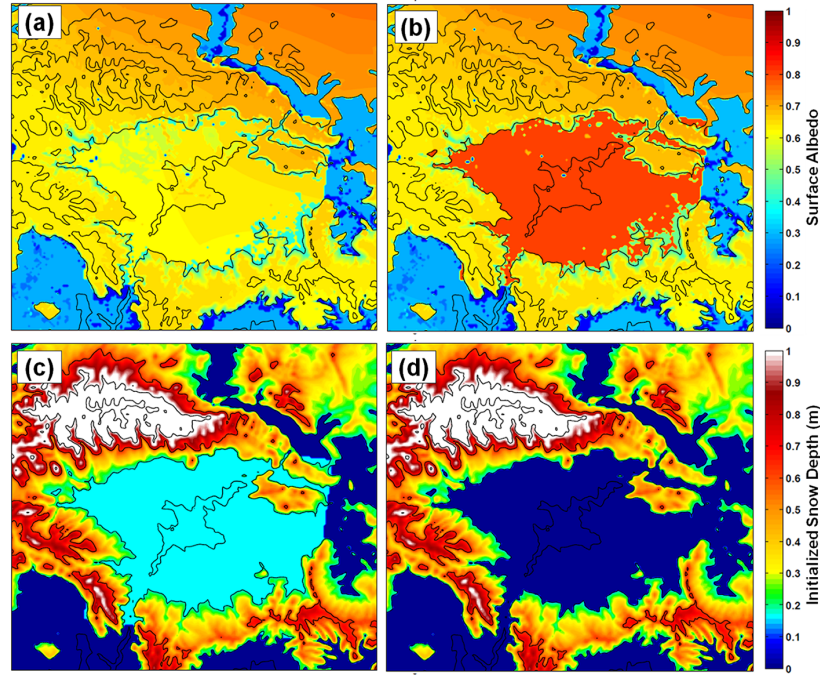

Figure 3. WRF surface albedo (top) at 18:00 MST 31 January 2013 for (a) before and (b) after modifications to WRF snow albedo and vegetation parameter table. Initialized snow depth (bottom, in m) at 17:00 MST 31 January 2013 for (c) "Full Snow" cases (BASE/FULL) and (d) "No Snow" case (NONE). Terrain contoured every $500 \mathrm{~m}$ in black.

and Roosevelt (HOR and ROO, respectively in Fig. 2b). The surface albedo averaged from 1 January to 2 March 2013 at Horsepool was 0.82 (Roberts et al., 2014), which is roughly 0.17 higher than the NAM analyses during the 31 January-
6 February period. Very low temperatures combined with repeated riming and/or ice fog deposition onto the snow surface during many nights apparently maintained the highly reflective surface within the basin. Hence, the snow albedo variable in WRF was initialized to be 0.82 inside the basin. Furthermore, based on visual observations of the snow covering nearly all of the sparse vegetation in the basin during the 31 January- 6 February period, changes were made to the WRF vegetation parameter table for the two dominant vegetation/land use types: "shrubland" and "cropland/grassland mosaic". For these vegetation types, $20 \mathrm{~kg} \mathrm{~m}^{-2}$ of SWE was allowed to fully cover the vegetation in the Noah land surface model. The combination of increasing the snow albedo and modifying the vegetation parameter table enabled the model surface to attain the high surface albedo observed during the field campaign (compare Fig. 3a to b).

\subsection{Numerical sensitivity studies}

Sensitivity tests were conducted with the WRF model to evaluate the impact of variations in cloud type and snow cover on CAPs in the Uintah Basin (Table 2). In order to test the sensitivity of the Uintah Basin CAP to ice-phase vs. liquid-phase cloud particles, the default Thompson microphysics scheme used in the BASE simulation was modified in the FULL simulation to enhance the production of ice fog and low clouds by turning off cloud ice sedimentation and the autoconversion of cloud ice to snow in the lowest 15 model layers ( $\sim 500 \mathrm{~m}$ a.g.l.). These changes allowed low- 
level cloud ice to remain suspended and thrive through vapor deposition due to the lower vapor pressure over ice compared to water. Recent research has shown that small ice particles suspended in ice fog have a much slower rate of gravitational settling than the ice particles found in cirrus clouds (for which the settling rates in the default WRF Thompson microphysics scheme were designed). Fall speeds are often less than $1 \mathrm{~cm} \mathrm{~s}^{-1}$ for small $(<20 \mu \mathrm{m})$ ice fog particles (Heymsfield et al., 2013; Schmitt et al., 2013; Kim et al., 2014), and can be more than 9 times slower than speeds calculated in the original Thompson scheme for particles smaller than $15 \mu \mathrm{m}$. Further, ice-dominant clouds have reduced radiative effects compared to liquid-dominant clouds (Shupe and Intrieri, 2004), allowing for stronger CAP formation, shallower planetary boundary layers (PBLs), and lower near-surface temperatures.

The BASE and FULL simulations use the prescribed snow cover as shown in Fig. 3c. As discussed in the Introduction, large snow cover variations are observed from one February to another in the Uintah Basin. To examine the sensitivity of the conditions in the basin to snow cover, the NONE simulation uses the same model configuration as the FULL simulation for the 31 January-6 February period but snow is removed for elevations below $2000 \mathrm{~m}$ in the basin (Fig. 3d), which is similar to what was observed during February 2012 and late February 2014.

\section{Results}

\subsection{Overview of the 1-6 February 2013 CAP}

A deep upper-level trough and associated mid-latitude cyclone moved across Utah from 28 to 30 January 2013, bringing very cold air aloft $\left(700 \mathrm{hPa}\right.$ temperatures $\left.\sim-20^{\circ} \mathrm{C}\right)$ and $1-5 \mathrm{~cm}$ of light snowfall on top of a $\sim 10-20 \mathrm{~cm}$ base to the Uintah Basin. Following the upper-level trough passage, 16 February was dominated by upper-level ridging over the western United States with large-scale subsidence and midlevel warming over the Uintah Basin. During the CAP, warm air aloft $\left(700 \mathrm{hPa}\right.$ temperatures between $\sim-7$ and $\sim 0{ }^{\circ} \mathrm{C}$ ) was observed overtopping very cold low-level air (diurnally ranging between $\sim-18$ and $-5^{\circ} \mathrm{C}$ ), which resulted in a strong capping inversion within the basin (Fig. 4a-b). In addition, the presence of fresh snow cover, quiescent surface weather conditions, and sufficient incoming solar insolation to drive photochemistry set the stage for a high ozone episode.

Low stratus and fog were commonly observed during the 31 January-6 February 2013 CAP in the lowest reaches of the basin, typically breaking up during the late morning and afternoon hours into hazy skies. A midday satellite image on 2 February 2013 indicates that the lower elevations of the Uintah Basin were snow covered, with fog and stratus confined to the lowest elevations of the basin (Fig. 5a). A Vis-
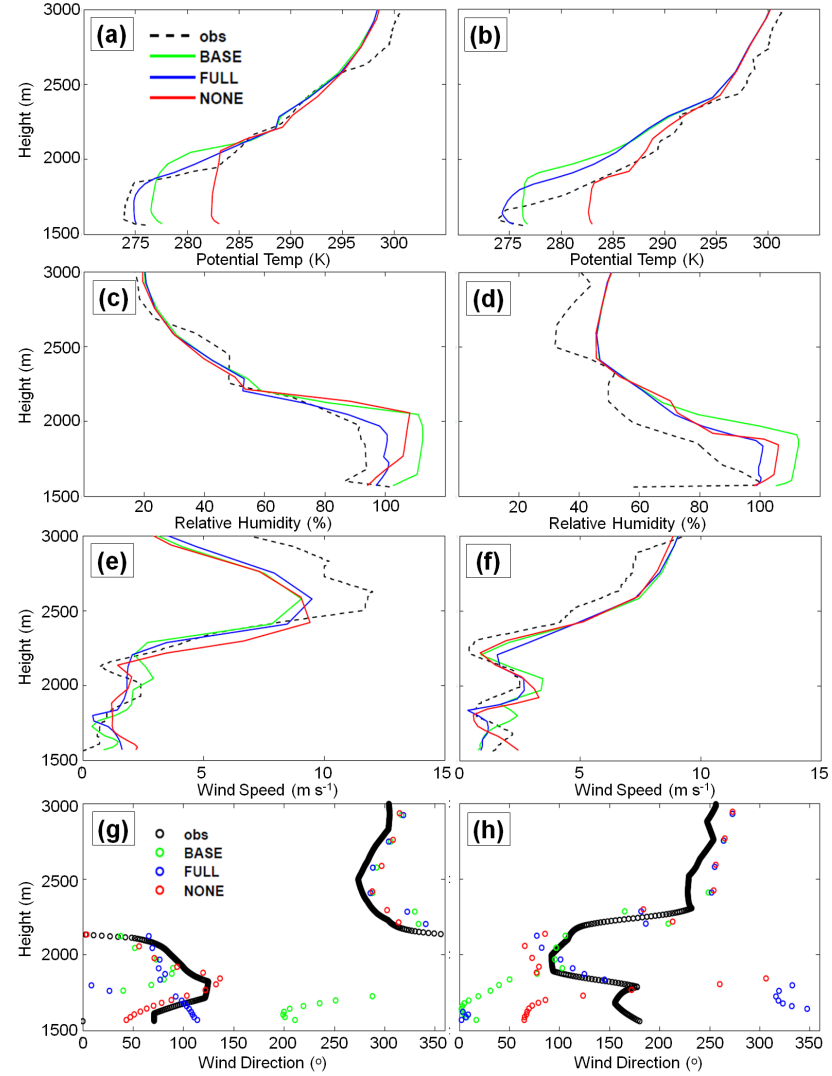

Figure 4. Observed and simulated vertical profiles at Roosevelt of (a, b) potential temperature, $(\mathbf{c}, \mathbf{d})$ relative humidity with respect to ice, $(\mathbf{e}, \mathbf{f})$ wind speed, and $(\mathbf{g}, \mathbf{h})$ wind direction for 11:00 MST 4 February 2013 (left) and 11:00 MST 5 February 2013 (right)

ible Infrared Imaging Radiometer Suite (VIIRS) nighttime microphysics RGB image taken during the previous night (Fig. 5b) provides evidence that the low clouds and fog in the basin may contain ice-phase particles. This product attempts to discriminate particle phase by combining data from the 3.9, 10.8, and $12.0 \mu \mathrm{m}$ infrared channels. Liquid-phase low stratus and fog are represented by aqua/green colors (e.g., southern ID and portions of western and central Utah), while the yellow/orange colors evident in the basin are typically associated with ice-phase stratus and fog. Since in situ cloud microphysics measurements were not obtained during the field campaign, unambiguously discriminating between ice and supercooled liquid water droplets is not possible. The elevation dependence of the fog/stratus is evident in Fig. 5b by the cloud tendrils extending up the river valleys within the basin. The clouds observed within the basin generally occurred within a high relative humidity layer located between the surface and $1800 \mathrm{~m}$ (Fig. 4c). The strong stability observed on 4 February extends upwards to $2750 \mathrm{~m}$ with decreasing moisture aloft. Weak easterly winds of $2-3 \mathrm{~m} \mathrm{~s}^{-1}$ at the base of the stable layer near $2000 \mathrm{~m}$ give way to westerly winds of $\sim 10-12 \mathrm{~m} \mathrm{~s}^{-1}$ near the top of the inversion layer 

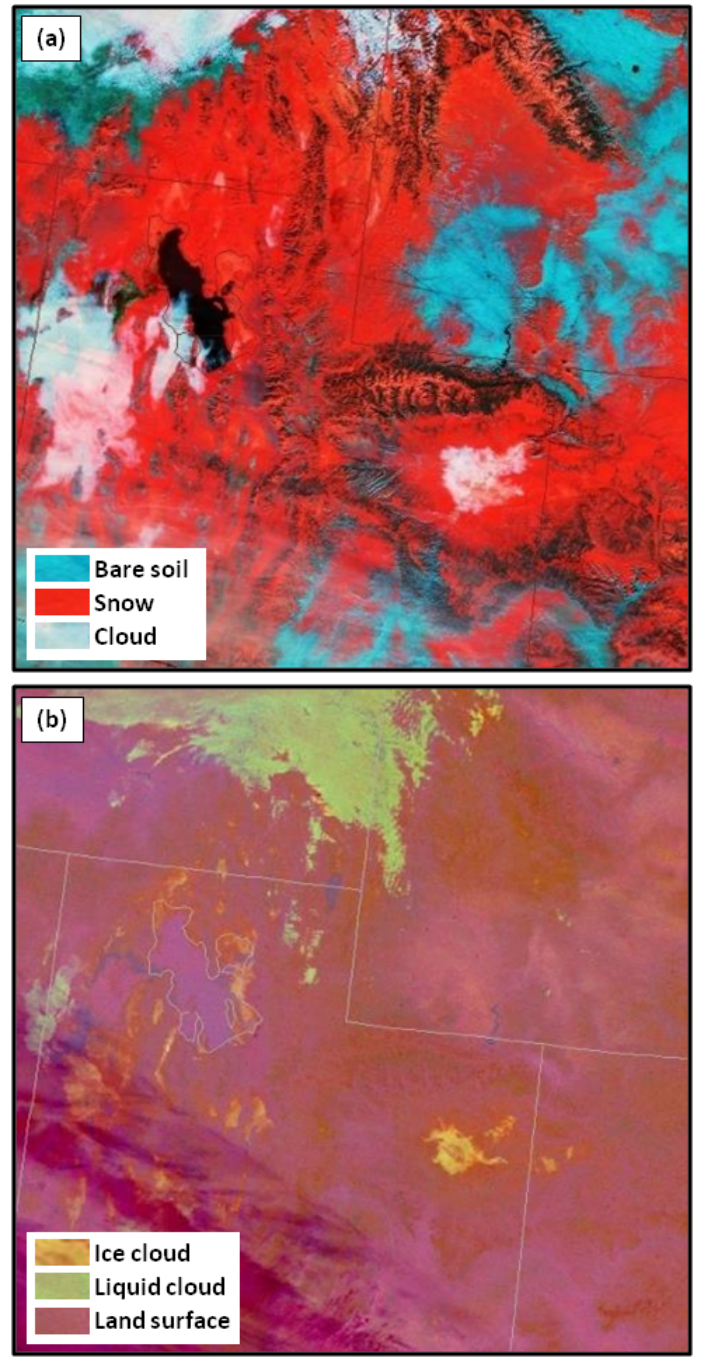

Figure 5. SPoRT-derived VIIRS satellite images: (a) Snow-Cloud product at 11:15 MST 2 February 2013 and (b) Nighttime Microphysics RGB product at 03:31 MST 2 February 2013.

(Fig. 4e and g). The observed mixed layer was shallower the following day as a result of a thinner near-surface fog layer (Fig. 4 b), with $\sim 10 \%$ lower relative humidity within the upper portions of the CAP. Weak easterly winds are present again near $2000 \mathrm{~m}$ with westerly winds of $7-9 \mathrm{~m} \mathrm{~s}^{-1}$ in the upper reaches of the capping stable layer. Vertical profiles of ozone and potential temperature from aircraft observations in the vicinity of Horsepool on 4 and 5 February confirm that a $\sim 150$ m lowering of the capping inversion occurred in this region as well between these two days (Figs. 17 and 18 in Oltmans et al., 2014). The lowering of the capping inversion resulted in an intrusion of clean air above the shallow stable layer on 5 February such that the highest boundary layer ozone concentrations extended to $\sim 1800 \mathrm{~m}$ on 4 February compared to $\sim 1600 \mathrm{~m}$ on 5 February (Figs. 17 and 18 in Oltmans et al., 2014).
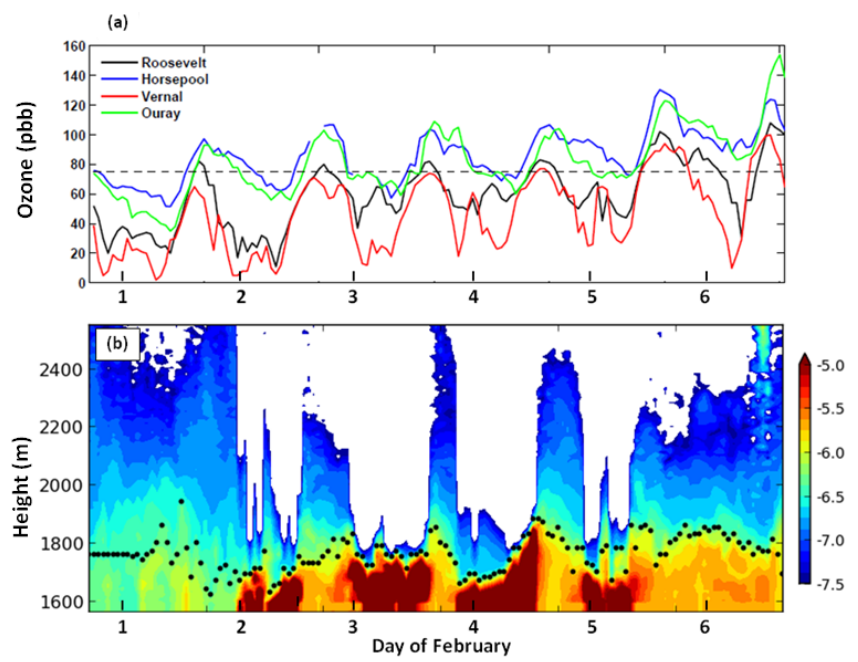

Figure 6. (a) Hourly ozone concentrations from 31 January to 6 February 2013 (thick black tick marks denote 00:00 MST) for Roosevelt (black), Horsepool (blue), Vernal (red), and Ouray (green) with the $75 \mathrm{ppb}$ ( $8 \mathrm{~h}$ mean) NAAQS denoted by the dashed line. (b) Ceilometer backscatter (shaded) and estimated aerosol depth (black dots) as a function of height (m) at Roosevelt from 31 January to 6 February 2013. Red, yellow, blue, and white shading denote fog and stratus clouds, high aerosol concentrations; low aerosol concentrations, and beam attenuation, respectively.

The observed ozone concentrations in the basin exceeded the EPA standard of $75 \mathrm{ppb}$ beginning during the afternoon of 1 February at Horsepool and Ouray (HOR and OUR in Fig. 2b) and continued to increase through 6 February (Fig. 6a). A weak weather system moved across the basin after 17:00 MST 6 February that lowered the ozone concentrations. However, elevated ozone levels continued until 9 February, after which a stronger weather system with sufficient cold-air advection aloft to destabilize the column moved through the region (not shown). Ozone concentrations near the small cities of Roosevelt and Vernal reach lower afternoon peaks and decrease to background levels at night as a result of $\mathrm{NO}_{\mathrm{x}}$ titration (Edwards et al., 2013; Lyman et al., 2014).

Figure $6 \mathrm{~b}$ presents the time evolution of aerosol backscatter, low clouds, and an estimate of the depth of the aerosol layer from the Roosevelt laser ceilometer during the 31 January-6 February period. Aerosol backscatter profiles collected at $16 \mathrm{~s}$ intervals are averaged into hourly profiles. Fewer aerosols were observed on 1 February followed early the next morning by the development of ice fog evident as well in Fig. 5b. Then, a semi-regular pattern developed over the next several days with shallow nighttime fog and low clouds thinning by midday and followed by a deeper layer of aerosols in the afternoon that quickly collapsed at sunset. The ceilometer backscatter data also corroborates other observations that the fog and low cloud occurrence in the basin peaked during 3-4 February. During that time, signifi- 
Table 3. $2 \mathrm{~m}$ temperature errors from WRF simulations. Mean errors calculated from the six surface stations in Fig. 1.5b during the 1-6 February 2013 period.

\begin{tabular}{llll}
\hline Simulation & Bias $\left({ }^{\circ} \mathrm{C}\right)$ & Mean abs error $\left({ }^{\circ} \mathrm{C}\right)$ & $\operatorname{RMSE}\left({ }^{\circ} \mathrm{C}\right)$ \\
\hline BASE & 1.65 & 3.25 & 3.97 \\
FULL & 0.11 & 2.44 & 2.98 \\
NONE & 7.71 & 7.74 & 8.29 \\
\hline
\end{tabular}

cant hoar frost was observed on trees and other surfaces after sunrise with light accumulations of ice crystals falling out of the fog in Roosevelt later in the morning. The high levels of aerosol backscatter on 5-6 February diminished near 17:00 MST 6 February as a result of the weak weather system mentioned earlier (not shown).

\subsection{BASE simulation}

WRF model simulations were conducted to improve our understanding of the spatiotemporal characteristics of temperature, wind, and moisture throughout the basin during the 31 January-6 February 2013 CAP and to investigate the role of snow cover and low clouds on the CAP's evolution (Table 2). Evaluation of the BASE model simulation on the $1.33 \mathrm{~km}$ inner grid relative to the available observations confirms that the WRF model captures the salient temperature, moisture and wind features of the CAP episode throughout the 31 January-6 February period above the boundary layer, i.e., above $\sim 2100 \mathrm{~m}$. For example, the simulated potential temperature profiles from the BASE simulation at elevations above $2100 \mathrm{~m}$ agree well with the observed midday profiles at Roosevelt (Fig. 4a and b). In addition, the weak easterly flow of $\sim 2 \mathrm{~m} \mathrm{~s}^{-1}$ observed between 1750 and $2050 \mathrm{~m}$ near the base of the stable layer aloft is also evident in the BASE simulation (Fig. $4 \mathrm{e}-\mathrm{h}$ ).

However, the simulated surface-based mixed layers at midday in the BASE simulation are unrealistically warm and deep compared to observations (Fig. $4 \mathrm{a}$ and $\mathrm{b}$ ). The $2 \mathrm{~m}$ temperature bias (model-observed) for the BASE simulation averaged over the six representative surface stations in the center of the basin is $1.65^{\circ} \mathrm{C}$ (Table 3). These biases are partially related to thick layers of liquid fog and stratus in the BASE simulation as demonstrated in the next subsection.

\subsection{Sensitivity to cloud type}

Straightforward modifications to the Thompson microphysics scheme (Sect. 2.3) employed in the FULL model run make it possible to examine the sensitivity of the CAP simulations to cloud type. As detailed in Table 2, the FULL simulation has cloud ice sedimentation and cloud ice autoconversion to snow turned off in the lowest 15 model levels. These modifications force the WRF model to produce and maintain clouds dominated by ice-phase particles, and effec-
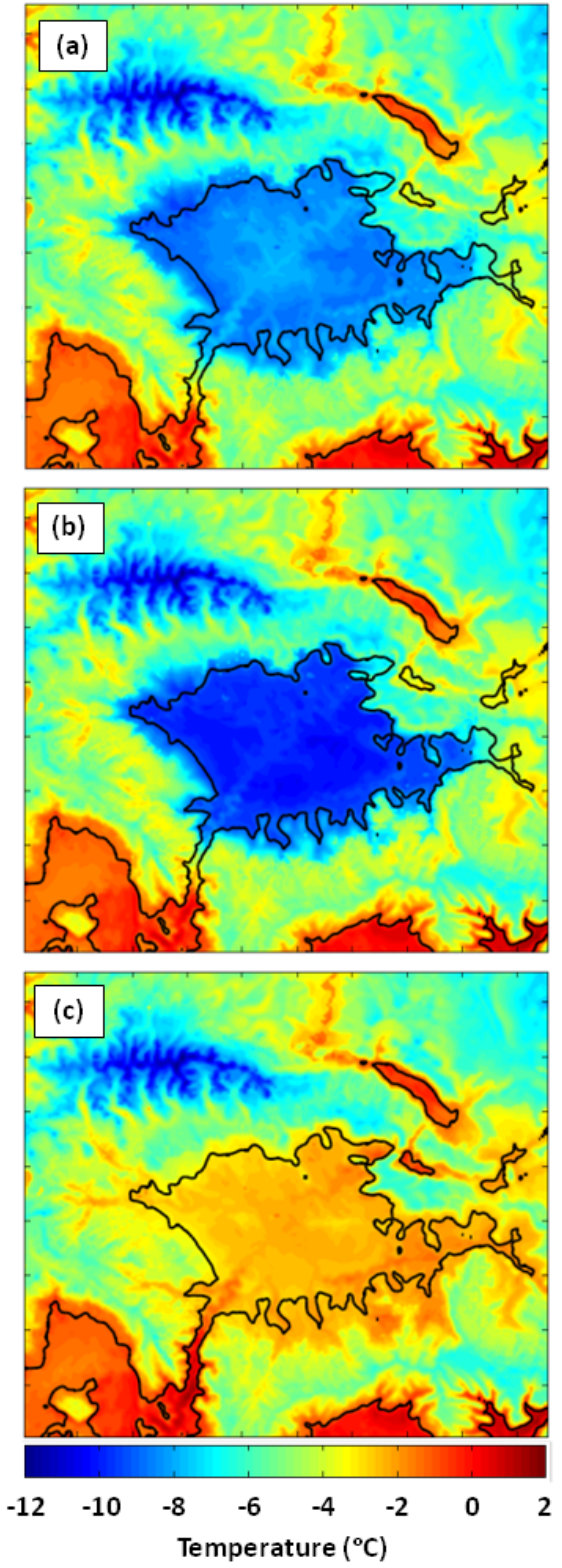

Figure 7. Average $2 \mathrm{~m}$ temperature (in ${ }^{\circ} \mathrm{C}$ according to the scale on the bottom) between 17:00 MST 31 January and 17:00 MST 6 February 2013 from (a) BASE, (b) FULL, and (c) NONE simulations.

tively act to achieve similar results as decreased gravitational settling rates introduced for ice fog by Kim et al. (2014). Returning to Fig. 4a and b, the midday potential temperature profiles at Roosevelt from the FULL simulation exhibit lower temperatures near the surface and a thinner CAP compared to the BASE simulation. Further, the bias and mean errors relative to the observations of the FULL simulation compared to the BASE simulation are reduced by $\sim 1{ }^{\circ} \mathrm{C}$ (Table 3 ). When averaged over the entire simulation period, the reduced $2 \mathrm{~m}$ temperatures throughout the basin demonstrate 

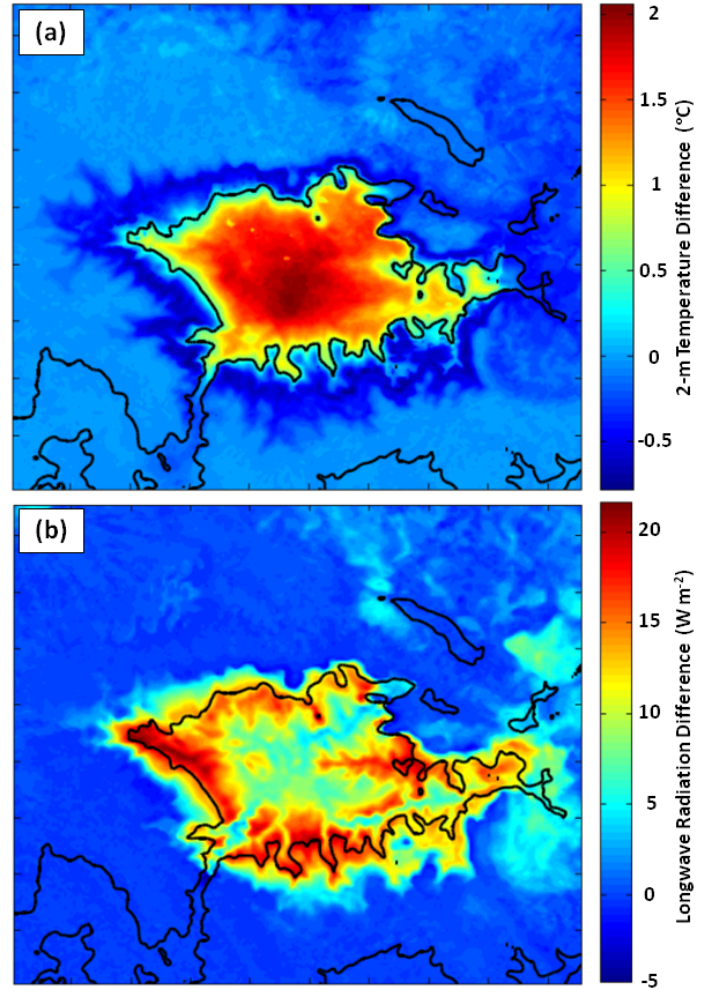

Figure 8. Average difference (BASE-FULL) for period 17:00 MST 31 January to 17:00 MST 6 February 2013 in (a) $2 \mathrm{~m}$ temperature (in ${ }^{\circ} \mathrm{C}$ according to the scale to the right) and (b) downwelling longwave radiation (in $\mathrm{W} \mathrm{m}^{-2}$ according to the scale on the right).

the colder CAP in the FULL simulation relative to the BASE simulation (Fig. 7). Figure 8 a indicates the $\sim 1.5^{\circ} \mathrm{C}$ difference between those two fields in the interior of the basin.

Comparing the temporal evolution of the potential temperature, cloud water, and ice profiles at Horsepool between the BASE and FULL simulations further illustrates the impact of cloud type on CAP thermodynamics (Fig. 9). The $1-3^{\circ} \mathrm{C}$ colder surface temperatures noted in the FULL compared to the BASE simulation are associated with extensive ice fog that occurred in the FULL simulation between the surface and the bottom of the capping inversion (Fig. 9a and b). The base of the capping inversion (approximately represented by the $\sim 280 \mathrm{~K}$ potential temperature isotherm in Fig. $9 \mathrm{a}, \mathrm{b}$ and the $\sim 290 \mathrm{~K}$ isotherm in Fig. 9c) associated with the top of the stratus clouds in BASE (Fig. 9a) averages 100-200 m higher than the top of the ice fog simulated in FULL, and the stratus clouds in BASE are on average 50-100 $\mathrm{m}$ deeper than the ice fog in FULL (Fig. 9b). Comparison of the modeled potential temperature profiles at Horsepool with nearby aircraft profiles presented by Oltmans et al. (2014) shows further that the simulated surface-based mixed layers at midday in the BASE simulation are unrealistically warm and deep by 100 $200 \mathrm{~m}$ compared to observations, while the FULL simulation mixed layers are improved but still remain too deep.
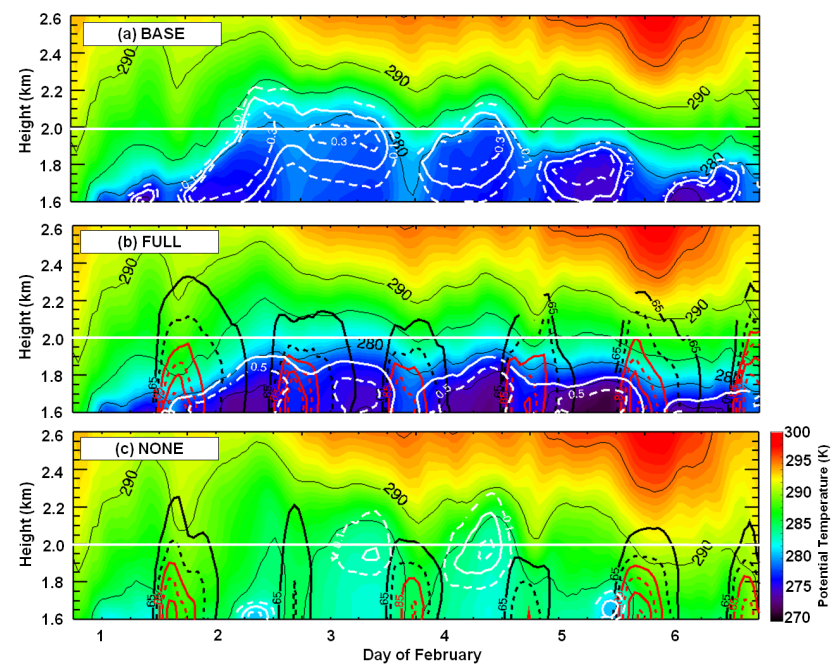

Figure 9. Time-height plot of potential temperature shaded in $\mathrm{K}$ according to the scale on the right at Horsepool from 17:00 MST 31 January to 17:00 MST 6 February 2013 (dates are labeled at 00:00 MST) from (a) BASE, (b) FULL, and (c) NONE simulations. Cloud water amounts in (a) and (c) of $0.1,0.2$, and $0.3 \mathrm{~g} \mathrm{~kg}^{-1}$ are denoted by dashed white, solid white, and dashed white lines, respectively. Cloud ice amounts in (b) of 0.3 and $0.5 \mathrm{~g} \mathrm{~kg}^{-1}$ are denoted by solid white and dashed white lines, respectively. Ozone concentrations are contoured every $10 \mathrm{ppb}$, starting at $65 \mathrm{ppb}$ and alternate between solid and dashed every $10 \mathrm{ppb}$. Ozone concentrations above (below) $85 \mathrm{ppb}$ are contoured in red (black). Plotted ozone concentrations represent the maximum value for each hour in a 40 by $40 \mathrm{~km}$ region encompassing Ouray and Horsepool.

The ice and liquid clouds simulated in FULL and BASE also have a diurnal cycle, with higher liquid and ice cloud amounts during the night than during the day, but the simulated cloud occurrences are overestimated in both simulations compared to ceilometer observations, particularly on 5 and 6 February (Figs. 6b and 9a, b). However, the shallow and surface-based clouds in FULL are more realistic in terms of the depth of the observed clouds than the deeper and elevated stratus clouds seen in the BASE simulation. In addition, the simulated vertical temperature profile in FULL also more closely matches available observations (e.g., Fig. 4a and b).

The improved vertical temperature and cloud profiles and $2 \mathrm{~m}$ temperatures in the FULL simulation are related to the depth and compositional change of the fog and stratus clouds in the CAP, i.e., deeper cloud water in the BASE simulation compared to shallower cloud ice in the FULL simulation. Snapshots of the cloud characteristics at 23:00 MST 4 February (Fig. 10) reflect similar total cloud (cloud water and ice) amounts and coverage. The BASE run is dominated by liquid-phase particles (Fig. 10c) while the FULL run is dominated by ice-phase particles (Fig. 10d). The preferential tendency for stratus clouds in the BASE simulation due to its deeper CAP leads to cloud cover extending outward farther 


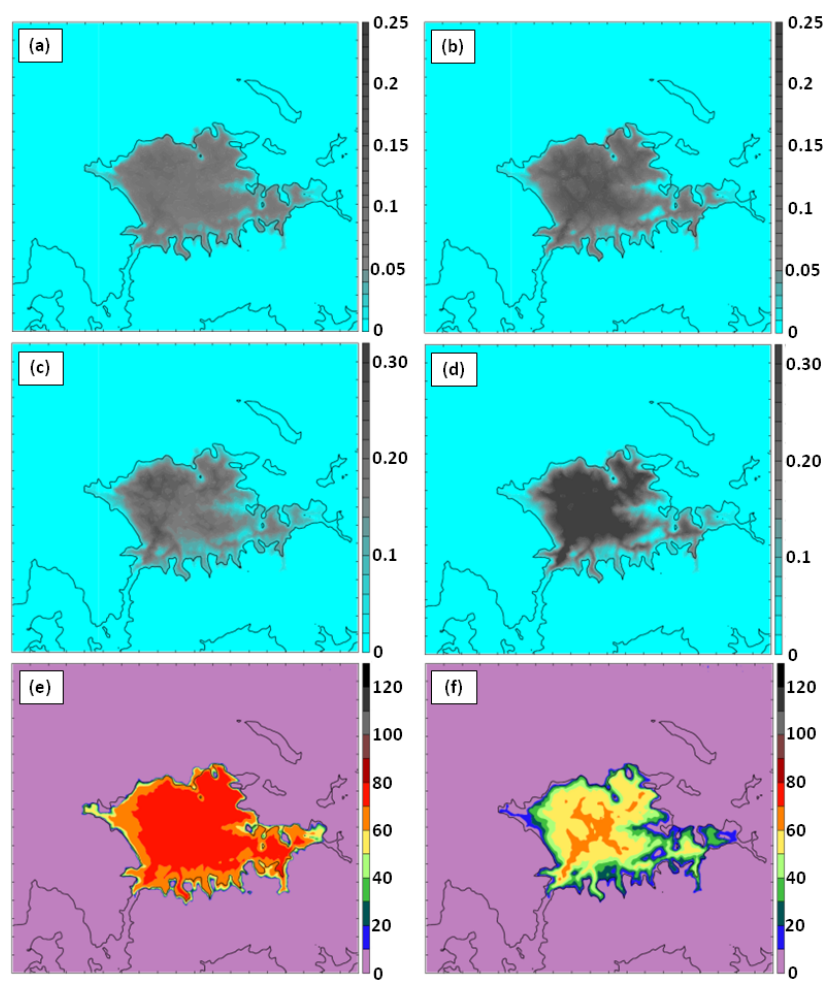

Figure 10. Cloud characteristics from BASE (a, c, e) and FULL (b, d, f) simulations at 23:00 MST 4 February 2013. (a, b) Integrated total cloud amount (cloud water and ice) in bottom 15 model levels (in $\mathrm{mm}$ according to the scale on the right), (c) mean cloud water in bottom 15 model levels (in $\mathrm{g} \mathrm{kg}^{-1}$ according to the scale on the right), (d) mean cloud ice in bottom 15 model levels (in $\mathrm{g} \mathrm{kg}^{-1}$ according to the scale on the right), (e, f) net downwelling longwave radiation from clouds (in $\mathrm{W} \mathrm{m}^{-2}$ according to the scale on the right).

away from the lowest elevations of the basin compared to the shallower surface-based fogs typically produced during the FULL run. Although the elimination of cloud ice sedimentation leads to greater cloud mass in that run relative to the BASE simulation (compare Fig. 10c to d), the cloud water in the BASE run results in $70-80 \mathrm{~W} \mathrm{~m}^{-2}$ of downwelling longwave radiation in the core of the basin while the cloud ice in the FULL run produces only $40-70 \mathrm{~W} \mathrm{~m}^{-2}$ over the same region (compare Fig. 10e to f). Averaged over the entire 6-day period, downwelling longwave radiation from the cloud water is $10-20 \mathrm{~W} \mathrm{~m}^{-2}$ more than from the cloud ice (Fig. 8b), which is consistent with the elevated temperatures over the entire period as well (Fig. 8a). The greatest difference in $2 \mathrm{~m}$ temperature is at the low elevations in center of the basin, while the greatest difference in longwave radiation is midway up the basin slope where cloud water is present in the BASE run and cloud ice is not found in the FULL simulation.

\subsection{Sensitivity to snow cover}

The simulation with no snow cover in the basin (NONE) for the 31 January-6 February 2013 period is now compared to the FULL simulation. The lack of snow in the basin increases the average CAP temperatures by as much as $8^{\circ} \mathrm{C}$ (Figs. 7 and 9), which is unrealistic relative to those observed (Table 3). While the CAP depth in the NONE simulation is also unrealistically deep (because this particular CAP was snow-covered), the lack of snow has negligible effects aloft (Figs. 4a and b, 9). Several interrelated processes contribute to the high low-level temperatures and deep afternoon CAP in the NONE simulation relative to the FULL simulation. First, when the snow is removed from the basin floor, the thermal conductivity of the land surface increases, and the decrease in surface albedo results in greater absorption of solar radiation. Second, the occurrence and thickness of the clouds in the warmer NONE boundary layer are reduced compared to FULL, resulting in greater incoming shortwave radiation (Fig. 9c). Finally, the sensitivity of the CAP to icephase microphysics is minimized in the NONE simulation since the boundary layer over the bare ground/vegetation is too warm (i.e., higher than $-12{ }^{\circ} \mathrm{C}$ ) to nucleate cloud ice. Where the clouds are present in the NONE simulation, the resulting liquid-phase stratus leads to increased longwave radiation at the surface.

The modeled afternoon mixed layer depths of $400-800 \mathrm{~m}$ in the NONE simulation were somewhat less than those observed in the basin during snow-free conditions in the 20112012 winter (Lyman and Shorthill, 2013). In addition, low clouds formed within the NONE simulations whereas they were not observed during undisturbed periods in the Uintah Basin during the previous winter 2011-2012. Further, recent WRF simulations for a cloud-free CAP episode during January 2013 produced periods of spurious low clouds (Trang Tran, personal communication), which suggests a moist bias to the modeled boundary layer characteristics in WRF that warrants further analysis.

\subsection{Flow features}

While the observations collected during the UBWOS field campaigns are the most extensive available to date for studying the thermodynamic and dynamic conditions in the Uintah Basin (Lyman and Shorthill, 2013; Stoeckenius and McNally, 2014), the majority of them consist of enhanced surface observations throughout the basin combined with vertical profiles at only a few locations (e.g., Horsepool, Ouray, and Roosevelt). The FULL simulation is used here to examine the four-dimensional fields of temperature, wind, and moisture to help identify relevant physical processes. We focus on several flow features evident in the FULL simulation that could be validated using the available data and which likely play an important role to transport pollutants within the CAP. 


\subsubsection{Clean-air intrusions into the basin}

CAP structure varies extensively, both temporally and spatially, over the course of the FULL simulation. Time height potential temperature profiles at Horsepool suggest that the CAP is initially confined to elevations below $1700 \mathrm{~m}$ before it deepens to a base near $1850 \mathrm{~m}$ early on 3 February (Fig. 9b). By midday on 4 February, the inversion base retreats to $1800 \mathrm{~m}$, and eventually lowers to $\sim 1700 \mathrm{~m}$ from early on 6 February through the end of the simulation. The CAP is continually modulated by synoptically driven midlevel flow atop the CAP, forcing it to "slosh" back and forth within the basin. Ridging aloft can lead to flow surmounting the surrounding terrain from nearly every direction from the southwest to the north. Downsloping flows mixing higher potential temperature and cleaner air downward into the basin are common and their impact depends on the stability and strength of the flow across the upwind barriers. For example, when the cross-barrier flow had a northerly component across the high Uinta Mountains during the 2013 winter, a notable strengthening of the inversion top due to subsidence warming of flow descending in the lee of the mountains was evident in the Uintah Basin (not shown).

The CAP may become displaced or tilted through hydrostatic and dynamic processes, which can then be disrupted by changes in wind speed above the CAP (Lareau and Horel, 2014). These disruptions produce gravity current features as the CAP rebounds, causing relatively large changes in depth (a few hundred meters) within just a few hours. Figure 11 shows an example of this type of behavior. Strong westerly flow crossing the mountain barrier to the west of the basin at 23:00 MST 3 February is highlighted by a narrow band of increased westerly to northwesterly flow at $2.3 \mathrm{~km}$ over the western portion of the basin (Fig. 11a). The cross section of potential temperature from west to east through the center of the basin at the same time is shown in Fig. 11b. The westerly downslope winds have eroded and depressed the CAP $\sim 200 \mathrm{~m}$ along the western basin slope. The FULL simulation suggests that weakening westerly winds over the next several hours lead to the CAP rebounding westward with the inversion base quickly rising to $\sim 1900 \mathrm{~m}$, roughly level with the rest of the basin (Fig. 11b). Lower ozone concentrations were also advected down the western slope of the basin by the westerly winds while the primary region of high ozone concentrations simulated in the eastern sector of the basin remained undisturbed (not shown).

\subsubsection{East-west cross basin transport}

Easterly flow immediately above the shallow mixed layer is evident in the midday soundings at Roosevelt on a number of days (Fig. 4). The ceilometer data at Roosevelt (Fig. 6b) as well as ozone tethersonde observations at Ouray (Schnell et al., 2014) suggest that aerosols, ozone precursors, and ozone extend upward into this layer of easterly flow likely as a

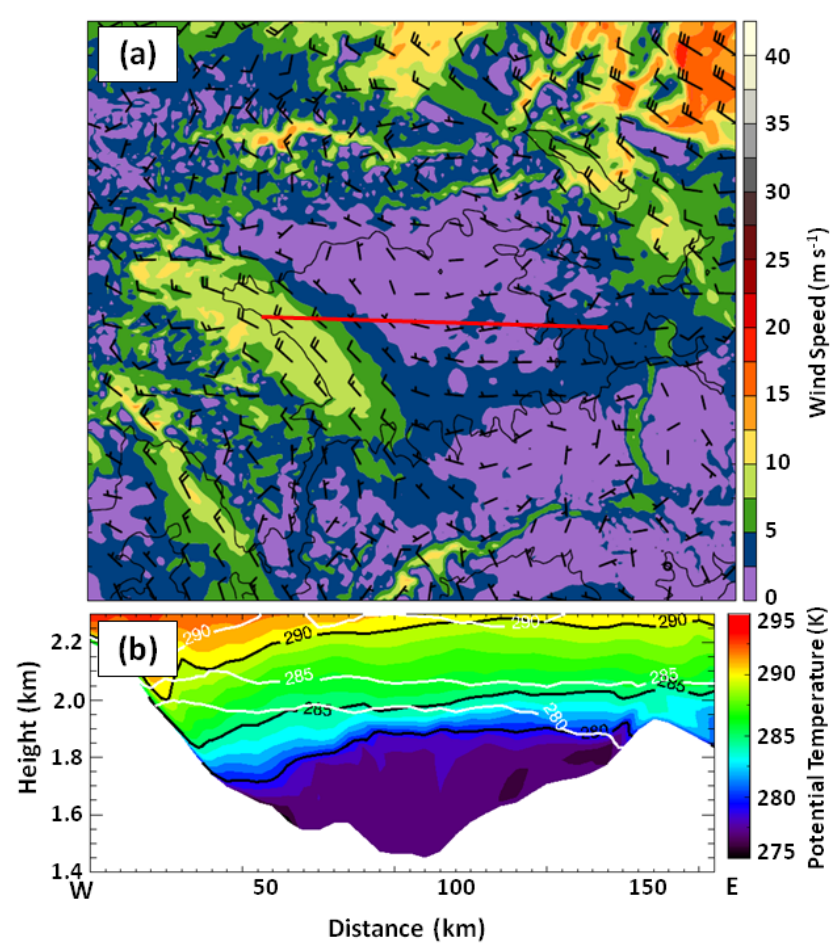

Figure 11. FULL simulation at 23:00 MST 3 February 2013 for (a) $2.3 \mathrm{~km}$ mean sea level (m.s.1.) wind speed (in $\mathrm{m} \mathrm{s}^{-1}$ according to the scale on the right) and barbs (full barb $5 \mathrm{~m} \mathrm{~s}^{-1}$ ). (b) Vertical cross section of potential temperature at 23:00 MST 3 February shaded in $\mathrm{K}$ according to the scale on the right and at 05:00 MST 4 February (in $\mathrm{K}$ according to labeled white contours) along red line in (a).

result of weak turbulence and entrainment (Cai and Luhar, 2002; Salmond, 2005). The ozone precursors from eastern basin source regions that are able to leak into the easterly flow layer may then be transported westward to portions of the basin that have more limited precursor sources, allowing ozone production to take place more widely (Karion et al., 2014; Oltmans et al., 2014).

Figure 12 shows the time-averaged zonal wind component from the FULL simulation along the cross section shown in Fig. 2b, split into daytime and nighttime periods. Synoptic westerly flow dominates above $2200 \mathrm{~m}$ with easterly flow present a few hundred meters above the basin floor. The core of the easterly flow coincides with the strongest stability (see Fig. 9b) in the basin and lies between 1800 and $2000 \mathrm{~m}$. Although this feature is relatively weak $\left(\sim 1 \mathrm{~m} \mathrm{~s}^{-1}\right.$ during the day, $0.5 \mathrm{~m} \mathrm{~s}^{-1}$ at night), it is persistent enough to appear as a coherent spatial pattern when averaged over the 6-day period. During the day, the core of the easterly flow is more intense aloft, and the east-west spatial extent is greater (compare Fig. 12a to b). At night, the easterly flow exhibits a weaker and more regional core shifted to the eastern portion of the basin and extending down to the surface (Fig. 12b). 


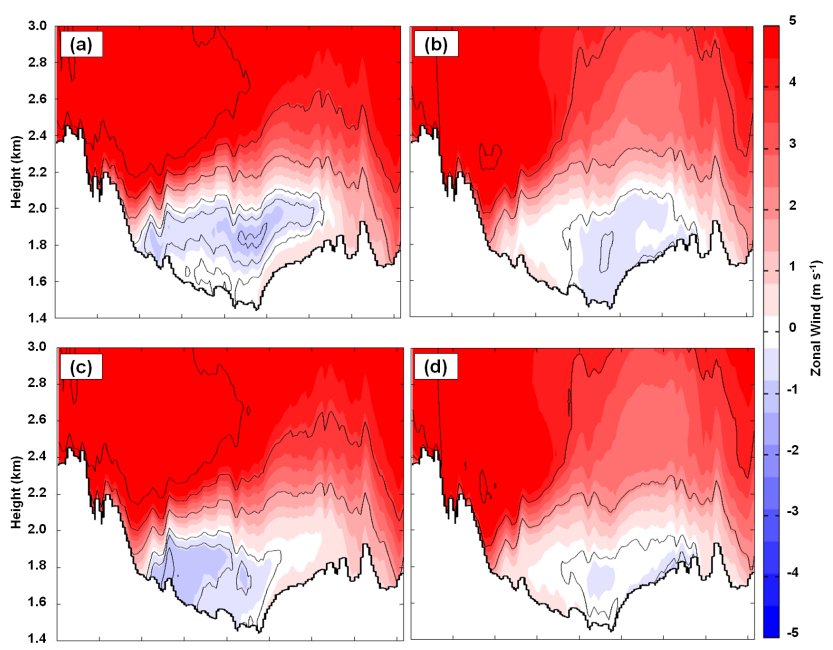

Figure 12. Average zonal wind in the vicinity of the cross section in Fig. 2b for 17:00 MST 31 January to 17:00 MST 6 February 2013 period. The FULL simulation (top) and NONE simulation (bottom) results for (a, c) daytime hours (08:00 to 17:00 MST) and (b, d) nighttime hours (18:00 to 07:00 MST). Westerly (easterly) winds shaded in $\mathrm{m} \mathrm{s}^{-1}$ according to the scale on the right in red (blue) with westerly (easterly) winds contoured every $2 \mathrm{~m} \mathrm{~s}^{-1}$ $\left(-0.5,-1\right.$, and $-2 \mathrm{~m} \mathrm{~s}^{-1}$ only). Values are averaged over a $26 \mathrm{~km}$ wide swath perpendicular to the cross section.

\subsubsection{Thermally driven valley and slope flows}

Thermally driven daytime upvalley/upslope and nighttime downvalley/downslope flows were observed within the basin by Lyman et al. (2013), while cross-basin elevated easterly flows $100-300 \mathrm{~m}$ a.g.l. (possibly associated with basinscale thermal gradients) were observed in rawinsonde soundings between 1 and 6 February 2013 at Roosevelt (Fig. 4). Within the model simulations, it appears that both additive and destructive interactions between the cross-basin elevated easterly flows and near-surface daytime upvalley/upslope and nighttime downvalley/downslope flows are occurring (Fig. 12). While basin-scale thermal gradients likely drive the elevated easterly flow, those gradients are at times in concert with and at other times interfering with more localized thermal gradients within drainages and along slopes. We hypothesize that the basin-scale thermal gradients are associated with either (1) elevated heating on the western slope of the basin, or (2) interactions between the westerly downslope flow, the cold-air pool, and the mountain slope.

During the night (Fig. 12b), drainage flows are evident from light westerly winds in the lowest $100 \mathrm{~m}$ a.g.l. on the west side of the basin in combination with light easterly winds on the east side. This pattern reverses during the day (Fig. 12a); however, the cross-basin easterlies appear to accentuate the upvalley/upslope winds at $\sim 1800 \mathrm{~m}$. As with any basin or mountain range, the diurnal flow patterns within the Uintah Basin are complex. An examination of mean wind direction during the day (not shown) highlights areas of upslope easterly flow within the CAP in the western half of the basin. Outside of the CAP, however, to the north and west of the basin, synoptic west-northwesterly flow dominates. This demonstrates how the strong stability above the CAP is able to effectively shield the basin interior from synoptic flows, allowing for weak thermally driven circulations to become important.

\subsubsection{Effects of snow cover on terrain-flow interactions}

The sensitivity of terrain-flow interactions to the presence or absence of snow cover in the Uintah Basin is briefly examined here. Comparison of the cross sections of time-averaged zonal winds from the FULL (Fig. 12a and b) and NONE (Fig. 12c and d) simulations are consistent with earlier results: the removal of snow cover only affects the near-surface atmosphere below the capping inversion. The weaker stability within the capping inversion in the NONE simulation likely allows the synoptic-scale westerlies to extend further down toward the basin floor. This extension appears to diminish the intensity of the easterly winds within the lower reaches of the inversion layer that would be expected in NONE given the lack of snow cover. Comparable differences are evident during the day (Fig. 12a and c) and night (Fig. 12b and d) with weaker and lower elevation easterly flow aloft when snow cover is removed. However, the intensity of the upvalley/upslope and downvalley/downslope flows near the surface remains largely the same and is actually increased during the day on the western side of the basin in the NONE simulation.

\section{Ozone}

\subsection{Overview}

The January-March 2013 period featured seven persistent CAPs with high ozone concentrations in the Uintah Basin (Stoeckenius and McNally, 2014). The CAP that began on 31 January led to increasing ozone concentrations over the next week (Fig. 6). Ozone concentrations started out relatively low on 31 January ( $\sim 20$ to $60 \mathrm{ppb}$ ) and gradually built to a maximum of $154 \mathrm{ppb}$ at Ouray on 6 February. Two key characteristics of ozone concentrations in the Uintah Basin are the (1) maintenance of high ozone levels above background levels over night in some areas of the basin, and (2) the pooling of the highest ozone values in lower elevations and river valleys, particularly in the southeastern quadrant near Horsepool and Ouray (Fig. 13). Data collected from ozonesondes and tethersondes during February 2013 show that the vertical extent of maximum ozone concentrations was typically limited to $1700 \mathrm{~m}$ and below, or in the lowest 200-300 m a.g.l. of the boundary layer (Schnell et al., 2014). A gradient in concentrations was noted above this level, with 


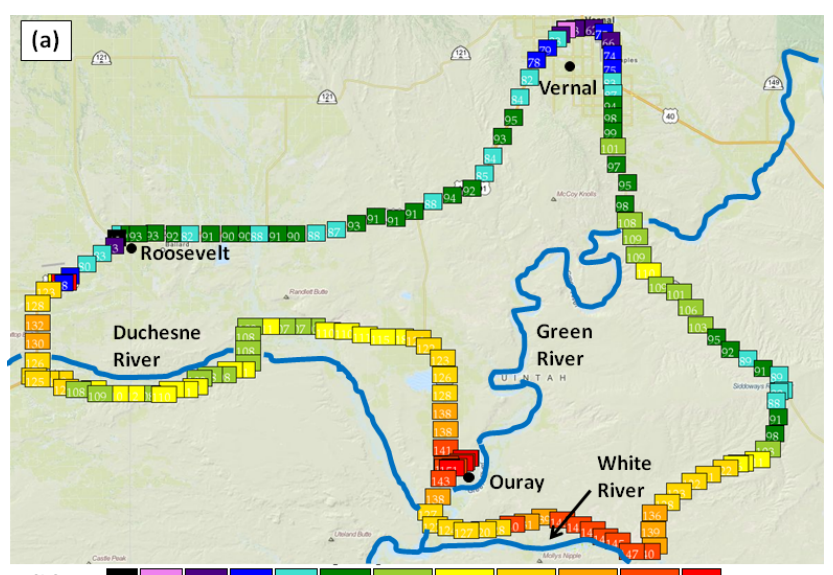

(b)

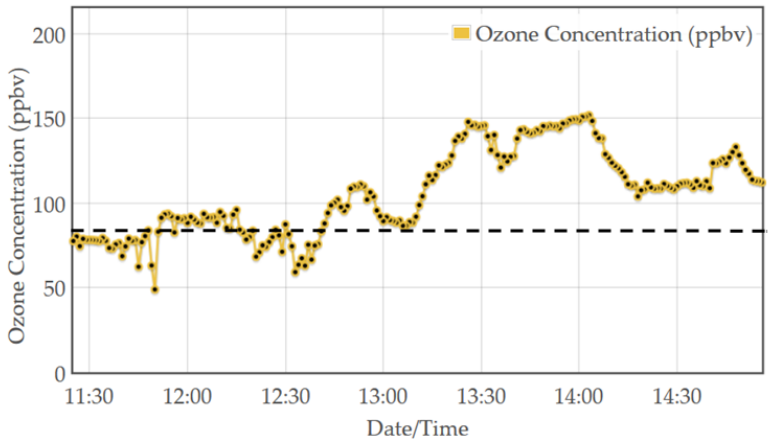

Figure 13. University of Utah Mobile transect of ozone concentration from 11:30 to 15:00 MST 6 February 2013 as a function of (a) geographic location and (b) time. Dashed black line represents NAAQS for ozone (75 ppb). Ozone concentrations in (a) are according to color scale.

ozone concentrations returning to background levels above 1900 m (Karion et al., 2014; Oltmans et al., 2014).

\subsection{Sensitivity of ozone concentrations to snow cover}

While ozone concentrations in the Uintah Basin are recognized to be strongly controlled by snow cover, the presence of snow has two complementary effects: (1) higher albedo enhancing photochemistry and (2) reduced near-surface temperatures; shallower CAP; and possibly enhanced east-west cross-basin transport a few hundred meters above the surface. For example, crude estimates of the actinic flux from the WRF FULL and NONE simulations provide an example of these complementary effects. The cloud ice typically present in the colder CAP found in the FULL simulation allows greater penetration of solar radiation to the surface than the cloud water observed between 2 and 4 February in the NONE simulation (Fig. 9b and c). Hence, more downward solar radiation during that time was then available to be reflected by the snow cover.

The objective of this phase of the study is to simply assess the sensitivity of WRF-CMAQ simulated ozone concentrations to snow cover during a CAP. The potential shortcom-
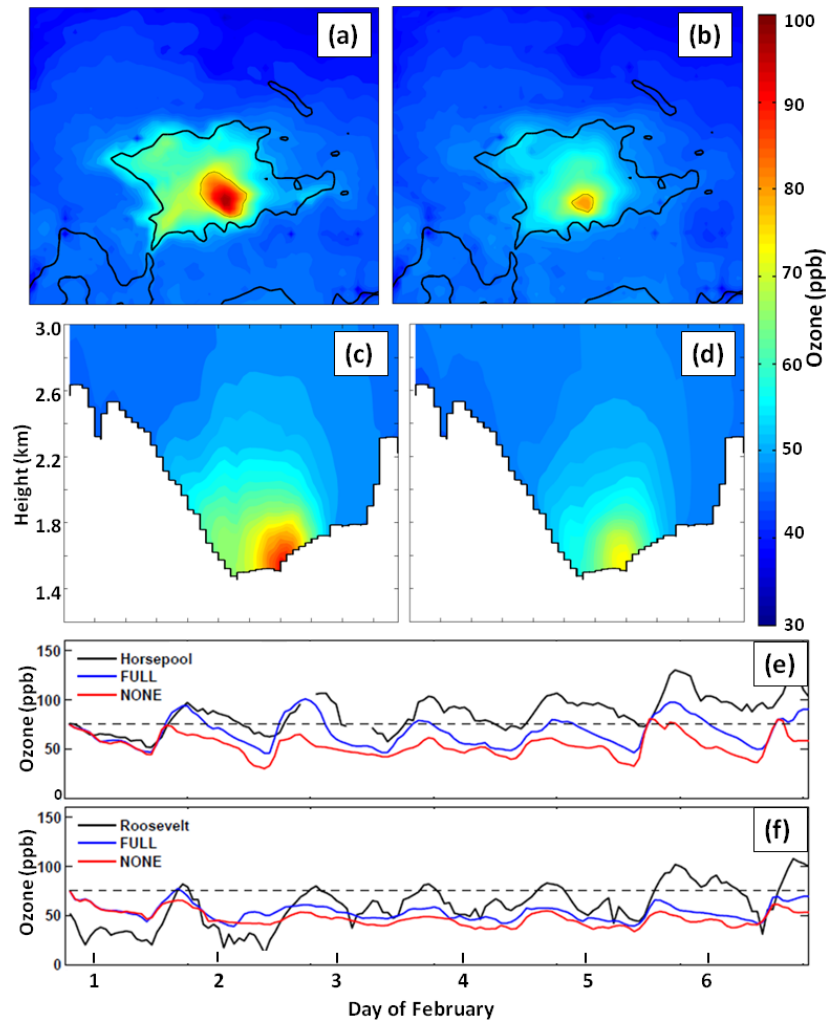

Figure 14. (top) Average ozone concentration (in ppb according to scale on the right) during 11:00-17:00 MST 1-6 February 2013 on the lowest CMAQ model level $(\sim 17.5 \mathrm{~m})$ from (a) FULL and (b) NONE simulations. The thin black line outlines regions where the ozone concentration exceeds $75 \mathrm{ppb}$ while the reference terrain elevation of $1800 \mathrm{~m}$ is shown by the heavy black line. (bottom) Average ozone concentration during 11:00-17:00 MST 1-6 February 2013 from (c) FULL and (d) NONE simulations along cross section approximately $25 \mathrm{~km}$ south of the red line in Fig. 2b. Values averaged over $24 \mathrm{~km}$ wide swath perpendicular to the cross section. Time series of ozone concentrations from (e) Horsepool, and (f) Roosevelt. Observations, CMAQ output from FULL and NONE simulations in black, blue, and red respectively (thick black tick marks denote 00:00 MST). The NAAQS of $75 \mathrm{ppb}$ is denoted by the thin black dashed line.

ings of driving CMAQ from imperfect atmospheric information and emissions inventories (Sect. 2.1) as well as the limitations of CMAQ are not addressed. The mean ozone concentrations near the surface throughout the basin averaged over the six afternoons (11:00 to 17:00 MST) from 1 to 6 February 2013 are generally 15-30\% greater when the CMAQ model is forced by the FULL simulation compared to the NONE simulation (compare Fig. 14a to b). As expected, ozone concentrations simulated by the CMAQ model are highest in the southeastern portion of the basin where the emission of ozone precursors $\left(\mathrm{NO}_{\mathrm{x}}\right.$ and VOCs) is greatest (Barickman, 2014). The region where average surface concentrations are greater than $75 \mathrm{ppb}$ is $\sim 6$ times larger in the FULL simulation than that in the NONE simulation. In addition, the peak 
ozone concentration simulated in the FULL case is $16 \mathrm{ppb}$ higher than that from the NONE case (Table 4), and the timing and magnitude of the peak value on 6 February in the FULL case is comparable to that observed (see Figs. 6 and 13). A comparison of east-west vertical cross sections of ozone (averaged along a $24 \mathrm{~km}$ wide swath approximately $25 \mathrm{~km}$ south of the red line in Fig. 2b) demonstrates the vertical extent of the higher ozone concentrations generated in the FULL vs. NONE simulations (Fig. 14c and d).

Ozone concentrations from the two CMAQ simulations are compared to those observed at Roosevelt and Horsepool in Fig. 14e and f. CMAQ struggles to simulate the ozone buildup at Roosevelt in the western portion of the basin whether snow is present or not (Fig. 14f). Closer to the primary precursor emission sources in the southeastern section of the basin, substantially higher ozone concentrations are evident at Horsepool in the FULL simulation compared to when snow is removed (Fig. 14e).

A time-height plot of ozone concentration and potential temperature at Horsepool from the FULL and NONE simulations helps to highlight some of the deficiencies of the CMAQ simulations for this case (Fig. $9 \mathrm{~b}$ and c). While the largest concentrations of ozone are confined within the CAP, elevated concentrations in excess of $75 \mathrm{ppb}$ extend higher than observed at Horsepool (Karion et al., 2014). In addition, CMAQ fails to build ozone concentrations from day to day through the event (Fig. 6). Instead, the highest concentrations appear to be controlled by the simulated mixed layer depth, e.g., concentrations are high during the late afternoon/early evening on 1 and 2 February, when the mixed layer is shallow, then they decrease on 3 and 4 February as the inversion base lifts to $\sim 1800 \mathrm{~m}$. As the inversion base lowers again on 5 and 6 February, concentrations increase with a maximum during the afternoon of 6 February. A similar evolution is noted in the NONE simulation, but the mixed layer is much deeper, concentrations are lower, and the maximum occurs on the afternoon of 5 February (Fig. 9c). However, the modeled ozone concentrations on some days with no snow cover appear to be unrealistically high compared to observations during other snow-free periods. While this inverse relationship between mixed layer depth and ozone concentrations is understandable physically, i.e., when the inversion base lowers it effectively decreases CAP volume, the observations during this case suggest other processes play a role as well.

\section{Summary and discussion}

The 31 January-6 February 2013 CAP in the Uintah Basin is examined and simulations are used to evaluate its sensitivity to cloud microphysics and snow cover. Output from meteorological simulations was input into the CMAQ model to relate ozone production to snow cover. The key findings of this study can be summarized as follows:
Table 4. Ozone concentration statistics from CMAQ model forced by FULL and NONE simulations during the 1-6 February 2013 period.

\begin{tabular}{lll}
\hline & FULL & NONE \\
\hline Highest mean $\mathrm{O}_{3}-$ afternoon $(\mathrm{ppb})$ & 97.2 & 81.2 \\
Highest mean $\mathrm{O}_{3}-$ non-afternoon $(\mathrm{ppb})$ & 61.9 & 51.0 \\
Maximum hourly $\mathrm{O}_{3}(\mathrm{ppb})$ & 134.4 & 118.0 \\
Area of mean afternoon $\mathrm{O}_{3}>75 \mathrm{ppb}\left(\mathrm{km}^{2}\right)$ & 896 & 144 \\
\hline
\end{tabular}

- The WRF mesoscale meteorological model was able to simulate a strong wintertime capping temperature inversion above the boundary layer within the Uintah Basin irrespective of surface or cloud characteristics.

- The CAP characteristics below $\sim 2100 \mathrm{~m}$ (stable layer intensity, vertical structure, and boundary layer flows) are heavily influenced by the presence of snow cover and are modulated to a lesser extent by the numerical treatment of cloud microphysics.

- The default settings in the Thompson microphysics scheme produce dense, liquid-phase low clouds and fog, whereas restricting cloud ice sedimentation and conversion to snow in the lowest model layers resulted in more realistic vertical profiles of temperature and low clouds.

- Intrusions of clean air into the basin as a result of terrain-flow interactions, east-west cross-basin advection above the surface, and shallow thermally driven slope and valley circulations are likely important factors for mixing pollutants throughout the Uintah Basin.

- CMAQ model-derived estimates of ozone concentrations agree better with observations (1) during the daytime than during the nighttime and (2) near the highly dense precursor emission sources located in the southeast quadrant of the basin (Fig. 14). The numerical simulations presented herein provide additional support to previous observational evidence that snow cover affects ozone concentrations by (1) cooling the near-surface layer and thereby strengthening the CAP and increasing stability further aloft, and (2) increasing the surface albedo and subsequent photolysis rates, contributing to rapid ozone production.

As in many model sensitivity studies focused on specific physical processes, there are a number of caveats to consider. First, the work presented here has been limited to a single CAP event. In order to obtain a more thorough understanding of how cloud microphysics and snow cover affect the evolution of CAPs, their wind flow patterns, and resulting impacts on air quality, further cases need to be examined. For example, if no clouds are allowed to form during the CAP lifecycle, this results in shallower mixed layer 
heights and a colder CAP by several degrees than that simulated with ice fog present (Neemann, 2014). Second, the modeling capability for the highly stable CAP meteorological conditions in the Uintah Basin lags behind typical meteorological situations; improvements in the parameterization of stable boundary layers and ice fog processes in numerical models are needed in order to obtain improved CAP simulations (Holtslag et al., 2013; Gultepe et al., 2014). Third, the idealized prescription of snow depth and albedo to constant values throughout the basin are imperfect estimates. Improvements in the representation of snow variables in meteorological and air quality models and analysis initialization fields in regions with shallow, persistent snow cover such as the Uintah Basin are needed. Fourth, additional data (particularly with regard to chemical species) exists in the eastcentral part of the basin (e.g., at Horsepool and Ouray) that could be used to evaluate meteorological and chemical model performance. Finally, significant uncertainty exists regarding precursor emission estimates within the basin. We elaborate further on several of these points in the following paragraphs.

As discussed by Gultepe et al. (2014), additional research is needed to understand ice fog microphysics and how to parameterize these processes in numerical models. Future research to investigate the impact of employing the recent WRF ice fog scheme of Kim et al. (2014) on cloud formation in the Uintah Basin is recommended. For this study, we neglected the fall speed of the ice fog particles to ensure that cloud ice was retained by the modified Thompson microphysics scheme. In addition, the effects of the unusually high ozone and particulate concentrations in the Uintah Basin on the ice nucleation processes are unknown, although studies suggest ice fog can be enhanced by anthropogenic activities (Benson, 1965; Kumai and O'Brien, 1965; Schmitt et al., 2013; Kim et al., 2014). While we did not find any perceptible difference in CAP simulations by varying the cloud droplet concentrations in the Thompson scheme from the default $\left(100 \times 10^{6} \mathrm{~m}^{-3}\right)$ to those typically assumed for continental $\left(300 \times 10^{6} \mathrm{~m}^{-3}\right)$ or hypothetical polluted continental $\left(1000 \times 10^{6} \mathrm{~m}^{-3}\right)$ situations, we recommend further testing along these lines, including testing the newly available aerosol-aware Thompson scheme (Thompson and Eidhammer, 2014).

Further work to improve parameterization schemes for modeling very stable boundary layers and their impact on CAP simulations is also needed (Baklanov et al., 2011). PBL schemes have difficulties handling low clouds, vertical temperature profiles, $2 \mathrm{~m}$ temperatures, and mixing in stably stratified conditions (Reeves et al., 2011; Shin and Hong, 2011; Zhang et al., 2013). Many schemes typically allow too much turbulent mixing in stable conditions, which results in boundary layers that are too deep (Holtslag et al., 2013). While the MYJ PBL scheme was ultimately selected for this study, the Asymmetric Convective Model, GrenierBretherton-McCaa, and Bretherton-Park PBL schemes were also tested in addition to the Yonsei University (YSU) scheme with and without the Jiménez surface layer formulation and updated stability functions (Jiménez et al., 2012). The MYJ was chosen because in simulating this particular CAP it best represented the combination of moisture, stability, and temperature characteristics that were observed in the Uintah Basin for the simulated period. Further testing of PBL schemes performance in the presence of high wind speeds above the stable PBL are also needed (e.g., Hu et al., 2013 found that modifications to the YSU nighttime velocity scale improved the simulations).

Snow cover and albedo were shown to have a prominent impact on simulated CAP evolution and ozone concentrations. However, in remote locations such as the Uintah Basin, where snow cover is typically very thin $(\sim 5-10 \mathrm{~cm})$ and variable, accurately assessing snow mass or water equivalent for input into numerical models can be difficult (Jeong et al., 2013). The impacts of modifying the albedo from the default NAM initialization to that observed (an increase of 0.17 , see Sect. 2.2) on the CAP meteorology were relatively small (not shown). However, larger impacts resulting from modest changes in snow albedo are likely to be observed within photochemical models (e.g., Ahmadov et al., 2014). Because of the spatiotemporal variability of snow depth and albedo within the Uintah Basin during winter seasons, the need for more sophisticated representation of snow variables in meteorological and air quality models in this region is apparent, and it is worthy of future research to better quantify the impact of these improvements on ozone simulations. Proper treatment of both the spatial extent of snow cover as well as the snow surface using a snow physics model driven by local atmospheric and chemical properties (e.g., the threelayer snow model within Noah Multi-Parameterization land surface model; Niu et al., 2011) may be needed to obtain a sufficiently accurate evolution of the snowpack and surface albedo. Additional research is also needed to understand the complex cycling of water over the thin snowpacks in the Uintah Basin and its impact on surface albedo, i.e., the interplay of very small sublimation rates, formation of ice fogs, and deposition of ice crystals back onto the snow surface.

Finally, as discussed in Sect. 2.1, the CMAQ emission inventory used in this study was prepared to represent oil and gas activities in 2011 (Barickman, 2014). The emission inventory and VOC speciation profiles for the Uintah Basin remain uncertain and are the subject of ongoing research (e.g., Warneke et al., 2014a, b). The recent work by Ahmadov et al. (2014) illustrates the effect of variations in emission scenarios on ozone levels within the Uintah Basin. Data collected during the 2013 UBWOS will add to the fidelity of these profiles as measurements are incorporated into future inventories. For example, a better understanding regarding how formaldehyde becomes highly concentrated in the basin (through direct emission or secondary chemical reactions) is needed. 
Acknowledgements. This research was supported by the Utah Division of Air Quality as part of the 2013 UBWOS and the Utah Office of Energy Development. We acknowledge the work of all agencies and participants in the 2013 UBWOS as detailed in the 2013 UBWOS Final Report, particularly Utah State University for meteorological and air quality data collection at Horsepool. The support and resources from the Center for High Performance Computing at the University of Utah are gratefully acknowledged. We thank the NASA SPoRT program for reprocessing satellite imagery used in this study. The first author gratefully acknowledges the support of the US Air Force Institute of Technology. The views expressed in this manuscript are those of the authors and do not reflect the official policy or position of the United States Air Force, Department of Defense, or the US Government.

Edited by: P. B. Shepson

\section{References}

Ahmadov, R., McKeen, S., Trainer, M., Banta, R., Brewer, A., Brown, S., Edwards, P. M., de Gouw, J. A., Frost, G. J., Gilman, J., Helmig, D., Johnson, B., Karion, A., Koss, A., Langford, A., Lerner, B., Olson, J., Oltmans, S., Peischl, J., Pétron, G., Pichugina, Y., Roberts, J. M., Ryerson, T., Schnell, R., Senff, C., Sweeney, C., Thompson, C., Veres, P., Warneke, C., Wild, R., Williams, E. J., Yuan, B., and Zamora, R.: Understanding high wintertime ozone pollution events in an oil and natural gas producing region of the western US, Atmos. Chem. Phys. Discuss., 14, 20295-20343, doi:10.5194/acpd-14-20295-2014, 2014.

Alcott, T. I. and Steenburgh, W. J.: Orographic influences on a Great Salt Lake-effect snow- storm, Mon. Weather Rev., 141, 24322450, doi:10.1175/MWR-D-12-00328.1, 2013.

Baklanov, A. A., Grisogono, B., Bornstein, R., Mahrt, L., Zilitinkevich, S. S., Taylor, P., Larsen, S. E., Rotach, W. M., and Fernando, H. J. S.: The nature, theory, and modelling of atmospheric planetary boundary layers, B. Am. Meteorol. Soc., 92, 123-128, doi:10.1175/2010BAMS2797.1, 2011.

Barickman, P.: Emission inventory development activities, in: Final report: 2013 Uinta Basin winter ozone study, edited by: Stoeckenius, T. and McNally, D., ENVIRON International Corporation, Novato, California, Chapter 9, 1-7, available at: http://www.deq. utah.gov/locations/uintahbasin/studies/UBOS-2013.htm (last access: 13 June 2014), 2014.

Bell, M. L., McDermott, A., Zeger, S. L., Samet, J. M., and Dominici, F.: Ozone and short-term mortality in 95 US urban communities, 1987-2000, J. Am. Med. Assoc., 292, 2372-2378, doi:10.1001/jama.292.19.2372, 2004.

Benson, C. S.: Ice fog: low temperature air pollution, Geophysical Institute of the University of Alaska, Fairbanks, Alaska, 198 pp., available at: www.dtic.mil/dtic/tr/fulltext/u2/631553.pdf (last access: 13 June 2014), 1965.

Billings, B. J., Grubišic, V., and Borys, R. D.: Maintenance of a mountain valley cold pool: a numerical study, Mon. Weather Rev., 134, 2266-2278, doi:10.1175/MWR3180.1, 2006.

Byun, D. and Schere, K. L.: Review of the governing equations, computational algorithms, and other components of the Models3 Community Multi-Scale Air Quality (CMAQ) modelling system, Appl. Mech. Rev., 59, 51-77, doi:10.1115/1.2128636, 2006.
Cai, X.-M. and Luhar, A. K.: Fumigation of pollutants in and above the entrainment zone into a growing convective boundary layer: a large-eddy simulation, Atmos. Environ., 36, 2997-3008, doi:10.1016/S1352-2310(02)00240-6, 2002.

Chen, R. and Dudhia, J.: Coupling an advanced land surfacehydrology model with the Penn State-NCAR MM5 modelling system. Part I: model implementation and sensitivity, Mon. Weather Rev., 129, 569-585, 2001.

Clements, C. B., Whiteman, C. D., and Horel, J. D.: Coldair-pool structure and evolution in a mountain basin: Peter Sinks, Utah, J. Appl. Meteorol., 42, 752-768, doi:10.1175/15200450(2003)042<0752:CSAEIA>2.0.CO;2, 2003.

Edwards, P. M., Young, C. J., Aikin, K., deGouw, J., Dube, W. P., Geiger, F., Gilman, J., Helmig, D., Holloway, J. S., Kercher, J., Lerner, B., Martin, R., McLaren, R., Parrish, D. D., Peischl, J., Roberts, J. M., Ryerson, T. B., Thornton, J., Warneke, C., Williams, E. J., and Brown, S. S.: Ozone photochemistry in an oil and natural gas extraction region during winter: simulations of a snow-free season in the Uintah Basin, Utah, Atmos. Chem. Phys., 13, 8955-8971, doi:10.5194/acp-13-8955-2013, 2013.

EPA: Air quality criteria for ozone related photochemical oxidants, EPA 600/R-05/004aF, US Environ. Prot. Agency, Research Triangle Park, NC, 821 pp., 2006.

EPA: SPECIATE 4.3: addendum to SPECIATE 4.2, speciation database development documentation, EPA/600/R-11/121, US Environ. Prot. Agency, Research Triangle Park, NC, 28 pp., available at: http://www.epa.gov/ttn/chief/software/speciate/ speciate4/addendum4.2.pdf (last access: 13 June 2014), 2011.

EPA: National ambient air quality standards (NAAQS), available at: http://www.epa.gov/air/criteria.html, (last access: 30 April), 2014.

Gultepe, I., Kuhn, T., Pavolonis, M., Calvert, C., Gurka, J., Heymsfield, A. J., Liu, P. S. K., Zhou, B., Ware, R., Ferrier, B., Milbrandt, J., and Bernstein, B.: Ice fog in arctic during FRAM- ICE fog project: aviation and nowcasting applications, B. Am. Meteorol. Soc., 95, 211-226, doi:10.1175/BAMS-D-11-00071.1, 2014.

Helmig, D., Thompson, C. R., Evans, J., Boylan, P., Hueber, J., and Park, J.-H.: Highly elevated atmospheric levels of volatile organic compounds in the Uintah Basin, Utah. Environ. Sci. Technol., 48, 4707-4715, doi:10.1021/es405046r, 2014.

Heymsfield, A. J., Schmitt, C., and Bansemer, A.: Ice cloud particle size distributions and pressure-dependent terminal velocities from in situ observations at temperatures from $0^{\circ}$ to $-86^{\circ} \mathrm{C}$, J. Atmos. Sci., 70, 4123-4154, doi:10.1175/JAS-D-12-0124.1, 2013.

Holtslag, A. A. M., Svensson, G., Baas, P., Basu, S., Beare, B., Beljaars, A. C. M., Bosveld, F. C., Cuxart, J., Lindvall, J., Steenveld, G. J., Tjernstrom, M., and Van De Wiel, B. J. H.: Stable atmospheric boundary layers and diurnal cycles: challenges for weather and climate models, B. Am. Meteorol. Soc., 94, 16911706, doi:10.1175/BAMS-D-11-00187.1, 2013.

Horel, J., Splitt, M., Dunn, L., Pechmann, J., White, B., Ciliberti, C., Lazarus, S., Slemmer, J., Zaff, D., and Burks, J.: Mesowest: cooperative mesonets in the western United States, B. Am. Meteorol. Soc., 83, 211-225, doi:10.1175/15200477(2002)083<0211:MCMITW>2.3.CO;2, 2002.

Hu, X. M., Klein, P. M., and Xue, M.: Evaluation of the updated YSU planetary boundary layer scheme within WRF for wind 
resource and air quality assessments, J. Geophys. Res.-Atmos., 118, 10490-10505, doi:10.1002/Jgrd.50823, 2013.

Iacono, M. J., Delamere, J. S., Mlawer, E. J., Shephard, M. W., Clough, S. A., and Collins, W. D.: Radiative forcing by long-lived greenhouse gases: calculations with the AER radiative transfer models, J. Geophys. Res., 113, D13103, doi:10.1029/2008JD009944, 2008.

Janjic, Z. I.: The Step-mountain eta coordinate model: further developments of the convection, viscous sublayer, and turbulence closure schemes, Mon. Weather Rev., 122, 927-945, doi:10.1175/1520-0493(1994)122<0927:TSMECM>2.0.CO;2, 1994.

Jeong, J.-H., Linderholm, H. W., Woo, S.-H., Folland, C., Kim, B.-M., Kim, S.-J., and Chen, D.: Impacts of snow initialization on subseasonal forecasts of surface air temperature for the cold season, J. Climate, 26, 1956-1972, doi:10.1175/JCLI-D-1200159.1, 2013.

Jiménez, P. A., Dudhia, J., González-Rouco, J. F., Navarro, J., Montávez, J. P., and García-Bustamante, E.: A revised scheme for the WRF surface layer formulation, Mon. Weather Rev., 140, 898918, doi:10.1175/MWR-D-11-00056.1, 2012.

Kain, J. S.: The Kain-Fritsch convective parameterization: an update, J. Appl. Meteorol., 43, 170-181, doi:10.1175/15200450(2004)043<0170:TKCPAU>2.0.CO;2, 2004.

Karion, A., Oltmans, S., Petron, G., Sweeney, C., and Schnell, R.: Analysis of aircraft observations, in: Final report: 2013 Uinta Basin winter ozone study, edited by: Stoeckenius, T. and McNally, D., ENVIRON International Corporation, Novato, California, chapter 4, 1-26, available at: http://www.deq.utah.gov/ locations/U/uintahbasin/studies/UBOS-2013.htm, last access: 22 December 2014.

Katurji, M. and Zhong, S.: The influence of topography and ambient stability on the characteristics of cold-air pools: a numerical investigation, J. Appl. Meteorol. Climatol., 51, 1740-1749, doi:10.1175/JAMC-D-11-0169.1, 2012.

Kim, C. K., Stuefer, M., Schmitt, C. G., Heymsfield, A. J., and Thompson, G.: Numerical modelling of ice fog in interior Alaska using the weather research and forecasting model, Pure Appl. Geophys., 1-20, doi:10.1007/s00024-013-0766-7, 2014.

Kumai, M. and O'Brien, H. W.: A study of ice fog and ice-fog nuclei at Fairbanks, Alaska, part II. US Army Materiel Command Cold Regions Research and Engineering Laboratory, Hanover, New Hampshire, 19 pp., available at: http://www.dtic.mil/cgi-bin/GetTRDoc?Location=U2\&doc= GetTRDoc.pdf\&AD=AD0676811 (last access: 13 June 2014), 1965.

Lareau, N. P.: The Dynamics of persistent cold-air pool breakup, $\mathrm{Ph} . \mathrm{D}$. thesis, University of Utah, Salt Lake City, Utah, 138 pp., 2014.

Lareau, N. P. and Horel, J. D.: Dynamically induced displacements of a persistent cold-air pool, Bound.-Lay. Meteor., doi:10.1007/s10546-014-9968-5, 2014.

Lareau, N. P., Crosman, E. T., Whiteman, C. D., Horel, J. D., Hoch, S. W., Brown, W. O. J., and Horst, T. W.: The persistent cold-air pool study, B. Am. Meteorol. Soc., 94, 51-63, doi:10.1175/BAMS-D-11-00255.1, 2013.

Lee, L., Wooldridge, P. J., Gilman, J. B., Warneke, C., de Gouw, J., and Cohen, R. C.: Low temperatures enhance organic nitrate formation: evidence from observations in the 2012 Uintah Basin
Winter Ozone Study, Atmos. Chem. Phys., 14, 12441-12454, doi:10.5194/acp-14-12441-2014, 2014.

Li, R., Warneke, C., Graus, M., Field, R., Geiger, F., Veres, P. R., Soltis, J., Li, S.-M., Murphy, S. M., Sweeney, C., Pétron, G., Roberts, J. M., and de Gouw, J.: Measurements of hydrogen sulfide $\left(\mathrm{H}_{2} \mathrm{~S}\right)$ using PTR-MS: calibration, humidity dependence, inter-comparison and results from field studies in an oil and gas production region, Atmos. Meas. Tech., 7, 3597-3610, doi:10.5194/amt-7-3597-2014, 2014.

Lippmann, M.: Health effects of tropospheric ozone: review of recent research findings and their implications to ambient air quality standards, J. Expo. Anal. Environ. Epid., 3, 103-129, 1993.

Lu, W. and Zhong, S.: A numerical study of a persistent cold air pool episode in the Salt Lake Valley, Utah, J. Geophys. Res.Atmos., 119, 1733-1752, doi:10.1002/2013JD020410, 2014. Lyman, S. and Shorthill, H. (Eds.): Final report: 2012 Uintah Basin winter ozone and air quality study, Commercialization and Regional Development, Utah State University, Vernal, Utah, 285 pp., available at: http://rd.usu.edu/files/uploads/ubos_2011-12_ final_report.pdf (last access: 13 June 2014), 2013.

Lyman, S., Mansfield, M., Shorthill, H., Anderson, R., Mangum, C., Evans, J., and Shorthill, T.: Distributed measurements of air quality and meteorology, in: Final report: 2013 Uinta Basin winter ozone study, edited by: Stoeckenius, T. and McNally, D., ENVIRON International Corporation, Novato, California, chapter 3, 1-35, available at: http://www.deq.utah.gov/locations/U/ uintahbasin/studies/UBOS-2013.htm, last access: 22 December 2014.

Malek, E., Davis, T., Martin, R. S., and Silva, P. J.: Meteorological and environmental aspects of one of the worst national air pollution episodes (January 2004) in Logan, Cache Valley, Utah, USA, Atmos. Res., 79, 108-122, doi:10.1016/j.atmosres.2005.05.003, 2006.

Neemann, E. M.: Analysis and simulation of a cold-air pool and high wintertime ozone episode in Utah's Uintah Basin, M.S. thesis, University of Utah, Salt Lake City, Utah, 94 pp., 2014.

Niu, G.-Y., Yang, Z.-L., Mitchell, K. E., Chen, F., Ek, M. B., Barlage, M., Kumar, A., Manning, K., Niyogi, D., Rosero, E., Tewari, M., and Xia, Y.: The community Noah land surface model with multiparameterization options (Noah-MP): 1. Model description and evaluation with local- scale measurements, J. Geophys. Res., 116, D12109, doi:10.1029/2010JD015139, 2011.

Oltmans, S. J., Karion, A., Schnell, R. C., Pétron, G., Sweeney, C., Wolter, S., Neff, D., Montzka, S. A., Miller, B. R., Helmig, D., Johnson, B. J., and Hueber, J.: A high ozone episode in winter 2013 in the Uinta Basin oil and gas region characterized by aircraft measurements, Atmos. Chem. Phys. Discuss., 14, 2011720157, doi:10.5194/acpd-14-20117-2014, 2014.

Pollack, I. B., Ryerson, T. B., Trainer, M., Neuman, J. A., Roberts, J. M., and Parrish, D. D.: Trends in ozone, its precursors, and related secondary oxidation products in Los Angeles, California: a synthesis of measurements from 1960 to 2010, J. Geophys. Res.Atmos., 118, 1-19, doi:10.1002/jgrd.50472, 2013.

Reeves, H. D. and Stensrud, D. J.: Synoptic-scale flow and valley cold pool evolution in the western United States, Weather Forecast., 24, 1625-1643, doi:10.1175/2009WAF2222234.1,2009.

Reeves, H. D., Elmore, K. L., Manikin, G. S., and Stensrud, D. J.: Assessment of forecasts during persistent valley cold pools in the Bonneville Basin by the North American Mesoscale 
Model, Weather Forecast., 26, 447-467, doi:10.1175/WAF-D10-05014.1, 2011.

Roberts, J. M., Veres, P. R., Yuan, B., Warneke, C., Geiger, F., Edwards, P. M., Wild, R., Dube, W., Petron, G., Kofler, J., Zahn, A., Brown, S. S., Graus, M., Gilman, J., Lerner, B., Peischl, J., de Gouw, J. A., Li, R., Bates, T., Quinn, P., Koss, A., Li, S.-M., Parrish, D. D., Senff, C. J., Langford, A. O., Banta, R., Martin, R., Zamora, R., Murphy, S., Soltis, J., and Field, R.: Analysis of aircraft observations, in: Final report: 2013 Uinta Basin winter ozone study, edited by: Stoeckenius, T. and McNally, D., ENVIRON International Corporation, Novato, California, Chapter 5, 1-96, available at: http://www.deq.utah.gov/ locations/U/uintahbasin/studies/UBOS-2013.htm, last access 13 June 2014.last access: 22 December 2014.

Salmond, J. A.: Wavelet analysis of intermittent turbulence in the very stable nocturnal boundary layer: implications for the vertical mixing of ozone, Bound.-Lay. Meteorol., 114, 463-488, doi:10.1007/s10546-004-2422-3, 2005.

Schmitt, C. G., Stuefer, M., Heymsfield, A. J., and Kim, C. K.: The microphysical properties of ice fog measured in urban environments of interior Alaska, J. Geophys. Res. Atmos., 118, 1113611147, doi:10.1002/jgrd.50822, 2013.

Schnell, R. C., Oltmans, S. J., Neely, R. R., Endres, M. S., Molenar, J. V., and White, A. B.: Rapid photochemical production of ozone at high concentrations in a rural site during winter, Nat. Geosci., 2, 120-122, doi:10.1038/NGEO415, 2009.

Schnell, R., Johnson, B., Cullis, P., Sterling, C., Hall, E., Albee, R., Jordan, A., Wendell, J., Oltmans, S., Petron, G., and Sweeney, C.: Tethered ozonesonde and surface ozone measurements in the Uintah Basin, winter 2013, in: Final report: 2013 Uinta Basin winter ozone study, edited by: Stoeckenius, T. and McNally, D., ENVIRON International Corporation, Novato, California, chapter 8, 1-48, 2014.

Shin, H. H. and Hong, S.-Y.: Intercomparison of planetary boundary-layer parameterizations in the WRF model for a single day from CASES-99. Bound.-Lay. Meteorol., 139, 261-281, doi:10.1007/s10546-010-9583-z, 2011.

Shupe, M. D. and Intrieri, J. M.: Cloud radiative forcing of the arctic surface: the influence of cloud properties, surface albedo, and solar zenith angle, J. Climate, 17, 616-628, doi:10.1175/15200442(2004)017<0616:CRFOTA>2.0.CO;2, 2004.

Silcox, G. D., Kelly, K. E., Crosman, E. T., Whiteman, C. D., and Allen, B. L.: Wintertime $\mathrm{PM}_{2.5}$ concentrations in Utah's Salt Lake Valley during persistent multi-day cold-air pools, Atmos. Environ., 46, 17-24, doi:10.1016/j.atmosenv.2011.10.041, 2012.

Stoeckenius, T. and McNally, D. (Eds.): Final report: 2013 Uinta Basin winter ozone study, ENVIRON International Corporation, Novato, California, 367 pp., available at: http://www.deq.utah. gov/locations/uintahbasin/studies/UBOS-2013.htm, last access: 13 June 2014
Sheridan, P. F., Vosper, S. B., and Brown, A. R.: Characteristics of cold pools observed in narrow valleys and dependence on external conditions, Q. J. Roy. Meteor. Soc., 140, 715-728, doi:10.1002/qj.2159, 2014.

Thompson, G. and Eidhammer, T.: A study of aerosol impacts on clouds and precipitation development in a large winter cyclone, J. Atmos. Sci., 71, 3636-3658, doi:10.1175/JAS-D-13-0305.1, 2014.

Thompson, G., Field, P. R., Rasmussen, R. M., and Hall, W. D.: Explicit forecasts of winter precipitation using an improved bulk microphysics scheme, Part II: Implementation of a new snow parameterization, Mon. Weather Rev., 136, 5095-5115, doi:10.1175/2008MWR2387.1, 2008.

Warneke, C., Geiger, F., Edwards, P. M., Dube, W., Pétron, G., Kofler, J., Zahn, A., Brown, S. S., Graus, M., Gilman, J. B., Lerner, B. M., Peischl, J., Ryerson, T. B., de Gouw, J. A., and Roberts, J. M.: Volatile organic compound emissions from the oil and natural gas industry in the Uintah Basin, Utah: oil and gas well pad emissions compared to ambient air composition, Atmos. Chem. Phys., 14, 10977-10988, doi:10.5194/acp14-10977-2014, 2014a.

Warneke, C., Veres, P. R., Murphy, S. M., Soltis, J., Field, R. A., Graus, M. G., Koss, A., Li, S.-M., Li, R., Yuan, B., Roberts, J. M., and de Gouw, J. A.: PTR-QMS vs. PTR-TOF comparison in a region with oil and natural gas extraction industry in the Uintah Basin in 2013, Atmos. Meas. Tech. Discuss., 7, 65656593, doi:10.5194/amtd-7-6565-2014, 2014b.

Whiteman, C. D., Zhong, S., Shaw, W. J., Hubbe, J. M., Bian, X., and Mittelstadt, J.: Cold pools in the Columbia Basin, Weather Forecast., 16, 432-447, doi:10.1175/15200434(2001)016<0432:CPITCB>2.0.CO;2, 2001.

Zängl, G.: Formation of extreme cold-air pools in elevated sinkholes: an idealized numerical process study, Mon. Weather Rev., 133, 925-941, doi:10.1175/MWR2895.1, 2005a.

Zängl, G.: Wintertime cold-air pools in the Bavarian Danube Valley Basin: data analysis and idealized numerical simulations, J. Appl. Meteorol., 44, 1950-1971, doi:10.1175/JAM2321.1, 2005b.

Zhang, H. L., Pu, Z. X., and Zhang, X. B.: Examination of Errors in Near-Surface Temperature and Wind from WRF Numerical Simulations in Regions of Complex Terrain, Weather Forec., 28, 893-914, doi:10.1175/Waf-D-12-00109.1, 2013. 